\title{
Study of high-tech process furnace using inherently safer design strategies (IV). Advanced NAND device design and thin film process adjustment
}

\author{
Chih-Cheng Lu' ${ }^{1}$, Kuo-Chi Chang ${ }^{1}$, Chun-Yu Chen*2
}

\author{
1 Institute of Mechanical and Electrical, Taipei University of Technology, Taipei 10608, Taiwan, ROC \\ *2 College of Design, Vanung University, Tao-Yuan 32061, Taiwan, ROC
}

\begin{abstract}
According to perspective of process design, using inherently safer design (ISD) strategies could obtain relatively safe levels, while meeting the existing product specification requirements. The experiences for semiconductor manufacturing processes in Taiwan were planning and completed civil construction first, and then followed regulatory limits to provide the maximum piping and equipment for process production line installed in facility area, unlike the general petrochemical industry planning program considerations, indeed often ignored safety consideration. The proposed configuration was the first time applied in NAND (abbreviation of Not AND) flash component technology. There have been no similar schemes used before as in this study, and also the industry has little exploration in this way. It is an important outcome of this study. In this study case, silane (SiH4) was changed to Tetraethyl Orthosilicate (TEOS) for the process to fit ISD substitution strategy of the overall wafer products, under product specification requirements, the more hazardous gaseous silane was replaced by liquid TEOS, thus, even if both have potential hazards of fire, explosion, and poisoning, as the liquid is less likely than gas to leak or diffuse, the potential hazards are reduced, rendering it inherently safer. In this study the potential hazards scenario of 22nm NAND Flash were analyzed first, then established process design proposal of 22nm NAND Flash; the design proposal was created according to the above potential hazard analysis results, then process design proposal simulation and verification were presented, followed by process design proposal experiment and verification in 12" tube, 16 batches of 22nm NAND Flash. There are 25 wafers per batch, and 16 batches of wafer cassettes tested according to the simulation results. The experiment result showed that the product yield increased from $83.88 \%$ of $\mathrm{SiH} 4$ to $84.25 \%$ of TEOS, which was good because the wafer surface defect is well controlled and the various processes have no significant deviation; the direct current (DC) property improvement was increased from $6.16 \%$ to $6.76 \%$, which might be due to the more dense liquid reaction with TEOS. In addition, the frequency response improvement increased from $4.97 \%$ to $5.16 \%$, due to the dense material related. Finally, the peeling ability improvement also increased from $4.27 \%$ to $4.36 \%$, as the TEOS liquid reaction was. The proposed process design improvement, as created in this study, could meet the expected process goals.粴
\end{abstract}

Keywords: Inherently Safer Design (ISD), High-Tech Plant, NAND Flash, Process Design, Process Tools.

\section{Introduction}

The gross output value of the IC industry formally passed the 2 trillion NTD mark in Taiwan in 2014, reaching 2.072 trillion NTD, while the optoelectronics industry reached 2.6007 trillion NTD in 2014 (Tsai \& Lin, 2014). It is obvious that the high-tech processes of semiconductor and optoelectronics industries are the main economic activities in Taiwan. The high-tech processes are mainly applied to logic operating, memory, chip, controller, and devices, usually called the Integrated Circuit (IC) in high-tech circles. The process must produce a transistor device on a wafer surface in order to simulate the complex functions of switch, resistor, capacitor, etc. Finally, a circuit with specific function is composed of a metal line. The process technologies include Physical Vapor Deposition (PVD), Chemical Vapor Deposition (CVD), Photolithography, dry/wet etching, thermal diffusion, ion implantation, oxidation, etc. (Sze \& Ng, 2006; Xiao, 2012). Large closed high-tech plant buildings are filled with toxic and inflammable chemicals, where fire, explosion, and chemical 
leak accidents occur occasionally, and such highly toxic, high-risk environments, and various disaster accidents render common people nervous and fearful of high-tech industry (Chen et al., 2014; Chang \& Chen, 2007a; Chang \& Chen, 2007b).

Common understanding on the ISD strategies, considering the application at the beginning of the construction planning stage, could be able to get the most of inherently safer level at the lowest cost.糎he experiences for semiconductor manufacturing processes in Taiwan were planning and completed civil construction first, and then followed regulatory limits to provide the maximum piping and equipment for process production line installed in facility area, unlike the general petrochemical industry planning program considerations, indeed often ignored safety consideration. The proposed configuration was the first time applied in NAND flash component technology. There have been no similar schemes used before as in this study, and also the industry has little exploration in this way. It is an important outcome of this study, let high-tech process to understand how to use the ISD strategies in component design stage to the whole plant.

As the memory foundry process is one of Taiwan's important high-tech products, this study was to investigate the scope of application and output value in order to improve the process design of Solid State Drive (SSD) products. Through using process design and further expanding the ISD substitution strategy make the whole process safer, in addition to the advanced technology-based SSD, because the advanced SSD technology mostly uses NAND Flash, and the component structure is developed from single-level cell (SLC) into the current multi-level cell (MLC), as emphasis remains on increasing product yield and storage capacity. At present, the advanced NAND Flash is made using $75 \mathrm{~nm}$ technology. Each cell size is reduced to below $0.0018(\mu \mathrm{m})^{2}$ by combining 8 levels of structure cells, which is almost equivalent to the floating gate NAND Flash component technology using the 22nm process(Chen et al., 2009; Kang et al., 2006; Katsumata et al., 2009). For consideration element operating speed of NAND flash components are generally the operation reliability, compatibility, size, power consumption, less expensive replacement and other new stable materials; the process design considerations contains process time , raw material input usage, the product yield of various stages, machine equipment functions. Essentially for safer process design, the sooner conduct ISD adopted will significantly reduce the hazards risk. Therefore, this study looks forward to using the aforementioned process starting from the component design, simulation and verification process followed by the ISD strategies into design considerations. The proposed system is for the first time applied in NAND Flash component design.

The current high-tech plant process safety management has two major management systems, the Occupational Health and Safety Assessment Series (OHSAS), as based on PDCA (Plan, Do, Check, Action) of quality control and the American "Process Safety Management of Highly Hazardous Chemicals (PSM)", as concluded in 1992. The former lays emphasis on hazard recognition, risk assessment, and risk control measures, while the latter has 14 categories, including Employee Participation, Mechanical Integrity, Process Safety Information, Hot Work, Process Hazard Analysis, Management of Change, Operating Procedures, Incident Investigation, Training, Emergency Planning and Response, Contractors, Compliance Audits, Pre-startup Safety Review, and Trade Secrets. Safety and health management systems emphasize the information and recognition of process hazards in order to consider inherently safer design for various potential hazards, as shown in Figure 1(Rasmussen, 1997; Kwon, 2006; Lu et al., 2014).

In order to smoothly attain the above process goals and prevent pollution by particulates, the process tools of the high-tech industry are placed in a cleanroom (as shown in Figure 2) (Chen et al., 2013a; Chen et al., 2013b). It is observed that the plant supply treatment systems of power, chemicals, toxic gas, pure water, and wastewater, are mostly installed on the floor below the cleanroom, and reach the Sub-FAB floor as a return air layer of the cleanroom by power delivery, entering the cleanroom process tools for operation via appropriate switchboard and VMB. Therefore, taking the general view of plant facilities, cleanroom environment, process tools, and internal reactors, they have the hazards of high temperature, gas leaks, fires, explosions, shocks, rolling and crimping, organic solvent poisoning, acid and alkali corrosion, hitting, and cutting universally according to the process requirements (as shown in Table 1) (Lu et al., 2014; Akkermans et al., 2004). While these hazards start from the process, the process is influenced by product features and process design, thus, if inherently safer design strategies are applied according to product features, the process design can be further improved, and the hazards restricted. In order to effectively increase the process safety level, the application of 
inherently safer design strategies is discussed from the process design. However, process safety design is seldom considered at present, and emphasis is mainly placed on factory building accidents and safety and health management, thus, it is difficult to identify research findings regarding inherently safer design strategies for process safety design(Leveson et al., 2009; Gill \& Shergill, 2004). Therefore, it is necessary to use inherently safer design strategies from the angle of process safety management to discuss process design and reduce potential hazards.

\section{Methodology}

For the joint defense disaster relief system of Taiwan's high-tech plant buildings, Chen et al. proposed an effective management system, as shown in Figure 3(Chen et al., 2013a). Inherently safer design strategies are adopted at the beginning of the process, and when such inherently safer design strategies are adopted, as possible, in the process stage, the application of inherently safer design strategies is reviewed for the overall machine, which is then extended to the overall facility end to discuss items successively. When the application of inherently safer design strategies is discussed, plant safety levels will certainly be effectively improved, and then the safety and health management system or process safety management system is used to guarantee the safe operation of plants. If the firms located in the overall science park adopt the same method, the preparedness of joint defense disaster relief, as well as the pressure of disaster prevention and protection, will be greatly reduced. Therefore, the key factors of the process design are more likely to be mastered through discussions of the key points, regarding the key items of process safety management, of the overall high-tech plant(Kletz,1984; Kletz, 1985; Khan \& Amyotte, 2002).

In terms of the potential hazards of the processes, Chen et al. proposed the application mechanism of inherently safer design strategies for high-tech plant buildings, as shown in Figure 4. The inherently safer design strategies of intensification, substitution, attenuation, and limitation of effects can be adopted for heat, electric, mechanical, and chemical energy sources. If energy sources cannot be effectively reduced, the inherently safer design strategies of avoiding knock-on effects can be adopted for the pipeline of energy sources within the buildings. Finally, the inherently safer design strategies of simplification, making status clear, rendering incorrect assembly impossible, tolerance, ease of control, and software, can be used by the operating personnel. Therefore, the expected degree of inherent safety can be effectively obtained by mastering the type, service condition, or capacity of energy sources. The energy source determines the type of potential hazards, including dropping, rolling, falling, hitting, object falling, object collapse, being hit, being crimped, being cut, trampling (trampling through), drowning, contacting high/low temperature, contacting hazardous materials, shocks, explosions, fires, and object breakup(Chen et al., 2013b; Kletz,1998; Khan \& Amyotte, 2003).

Figure 5 showed the high-tech process furnace using ISD strategies focused in a series of author studies ideas for reader's reference (Chen et al., 2013a; Chen et al., 2013b; Lu et al., 2014). Therefore, Table 2 summarized a series of studies of applied ISD strategies in the past were to explore on temperature distribution model and process effect, focus on simulation model applied for a vertical furnace could provide data on furnace temperature control for industrial use, then established that deposited film thickness model, this study validated four types of process conditions, and found that the results were very close to the experimental values in the previous studies, thus concluded that the proposed process film thickness mode could meet the requirement of the process capacity, Series No.3 topic discussed the advanced thin film process and reduction of power consumption, in the process of the first batch, as there were only 100 wafers, the $5^{\text {th }}$ heating zone was shut off, thus, 18.05A was reduced by shutting off the $5^{\text {th }}$ heating zone. The machine had a voltage of $220 \mathrm{~V}$ and converted power output up to $3971 \mathrm{~W}$, accounting for $26 \%(15265.8 \mathrm{~W})$ of the entire machine, from the process conditions expanded to process machines and facility system. In addition, the experiences for semiconductor manufacturing processes in the Taiwan were planning and complete civil construction first, and then followed regulatory limits to provide the maximum piping and equipment for process production line installed in facility area, unlike the general considerations of petrochemical industry planning program. Semiconductor plant in the aforementioned plan also applied Failure Mode and Effects analysis (FMEA), Hazards and Operability Studies (HAZOP), or other analysis tools for safety prevention (Tay \& Lim., 2006; Whitcomb \& Rioux., 1994; Trammell \& Davis., 2001; Pole., 2003). There was less directly to discuss on the ISD strategies application, these easily led to complete machine installation, and then installed safety measures, This is inconsistent with 
the spirit of ISD strategies. The proposed configuration in this study was for the first time applied in NAND flash component technology. There have been no similar schemes used before as in this study, and also the industry has little exploration in this way. It is an important concept of this study.

And for the semiconductor manufacturing process, the 2015 main process capability of Taiwan Semiconductor Manufacture Company ( TSMC), or Samsung (Korea) is about 20nm ( refer Figure 6). This study took the advanced manufacturing process 22nm NAND Flash as the main research focus, in order to fit the specifications of the main products currently on the market. In advanced Logic Product Architecture of 22nm IC, which STI (shallow trench isolation), the sidewall spacer, PMD (pre-metal dielectric), and IMD (inter-metal dielectric) and other components configured (shown in Figure 7) were often used silane. However, silane was gaseous pyrophoric substances, as long as leaking contact with the room temperature possibly causing spontaneous combustion and explosion (shown in Table 3). Some incidents of explosions happened in solar cell manufacturers in Taiwan. TEOS is an organic molecule, having a high surface mobility, CVD film deposition with TEOS-based generally has good step coverage and the ability to fill in the ditch, so it could be widely used for depositing TEOS oxide, so this study was to investigate the ISD substitution strategies, to discuss the product design review and adjustment process, replaced silane to more safe TEOS to achieve the product specification requirements (Sze \& Ng, 2006; Xiao, 2012).

In the past, the main processes used the $\mathrm{SiH}_{4}$ for $\mathrm{SiO}_{2}$, and the reaction was shown in the formula (1) (Sze \& Ng, 2006; Hong Xiao, 2012):

$$
\mathrm{SiH}_{4}+\mathrm{O}_{2} \rightarrow \mathrm{SiO}_{2}+2 \mathrm{H}_{2}
$$

In this study, TEOS was used as the raw material. TEOS is an organic molecule that has high surface mobility. CVD thin film deposition, as based on TEOS. It generally has good step coverage and trench filling ability, and is widely used in the deposition of oxide, including STI, sidewall spacer, PMD, and IMD. TEOS is in the liquid state at room temperature. During application, heating the TEOS container (about 40 70乃) increases its saturated vapor pressure for the convenience of application in the gas state. As TEOS has a very high boiling point (about 169乃 at atmospheric pressure), in the CVD process application and under high temperature, TEOS can only have the reaction of Eq. (2) due to its need for adequate heat in order to further generate the $\mathrm{SiO}_{2}$. As a result, the furnace tube was commonly used for this process. Eq. (2) used the reaction formula of TEOS generating $\mathrm{SiO}_{2}$ (Desu et al ., 1989; Fujino et al., 1990; Granier et al., 2003; Sze \& Ng, 2006; Hong Xiao, 2012).

$$
\mathrm{Si}\left(\mathrm{C}_{2} \mathrm{H}_{5} \mathrm{O}\right)_{4(g)} \longrightarrow \mathrm{SiO}_{2(s)}+4 \mathrm{C}_{2} \mathrm{H}_{4(g)}+2 \mathrm{H}_{2} \mathrm{O}_{(g)}
$$

From Eq.(2) and Desu (1989), the reaction kinetics for $\mathrm{SiO}_{2}$ were shown in Eqs. (3), (4), (5), and (6):

1. TEOS decomposition in gas phase:

$$
\mathrm{Si}\left(\mathrm{C}_{2} \mathrm{H}_{5} \mathrm{O}\right)_{4} \longrightarrow \mathrm{kg}+\mathrm{R}_{1}
$$

2. Adsorption reaction:

$$
I \underset{\mathrm{k}_{\mathrm{a}}}{\longrightarrow} I^{*}
$$

3. Surface chemical reaction:

$$
I^{*} \stackrel{k_{d}}{\longrightarrow} \mathrm{SiO}_{2}+R_{2}+*
$$

4. The deposition reaction rate: 


$$
r=\frac{k_{d} K_{a}\left(K_{g} C\right)^{0.5}}{1+K_{a}\left(K_{g} C\right)^{0.5}}\left(\frac{\text { mole }}{\mathrm{cm}^{2} \cdot \mathrm{s}}\right)
$$

where

r: Deposition rate $\left(\frac{\text { mole }}{\mathrm{cm}^{2} \cdot \mathrm{s}}\right)$

$\mathrm{C}:$ Gas concentration of TEOS $\left(\frac{\text { mole }}{\mathrm{cm}^{3}}\right)$

R: Gas constant

$\mathrm{T}$ : The reaction temperature $(\mathrm{K})$

$$
\begin{aligned}
& K_{g}=1.38 \times 10^{4} \exp (-299240 / 8.314 T)\left(\frac{\mathrm{mol}}{\mathrm{cm}^{3}}\right) \\
& K_{a}=1.14 \times 10^{10} \exp (-21422 / 8.314 T)\left(\frac{\mathrm{cm}^{3}}{\mathrm{~mol}}\right) \\
& k_{d}=4.74 \times 10^{-8} \exp (-12259 / 8.314 T)\left(\frac{\mathrm{mol}}{\mathrm{cm}^{2} \cdot \mathrm{s}}\right)
\end{aligned}
$$

The assumed conditions of this study were as follows:

1. 1 -D mode.

2. The thin film deposition of the isotropic phase is uniform.

3. The reaction occurs only on the effective area.

4. Isotropic thin film deposition.

5. The temperatures of wafers are uniform.

6. TEOS is plug flow.

7. The trench reaction deposition is not considered.

The LPCVD reactor conditions in this study was shown in Table 4:

The main research method and procedures were based on research motive and purpose of this study, as shown in Figure 8. First, the potential hazards scenario analysis applied ISD strategies of 22nm NAND Flash were analyzed, then established process design proposal. The design proposal was created according to the above potential hazards analysis results after applied ISD strategies, then process design proposal simulation and verification after applied ISD strategies of 22nm NAND Flash were presented, followed by process design proposal experiment and verification after applied ISD strategies in 12” tube, 16 batches of 22nm NAND Flash. The proposed process design improvement after applied ISD strategies, as created in this study, could meet the expected process goals. Finally, the ISD strategies applied to the process and machine.

\section{Process hazard analysis and design proposal review of applied ISD strategies}

The single-level NAND Flash, multi-level NAND Flash, NAND Flash, and NOR Flash are compared in 
Figure 9 (Irom \& Nguyen, 2007; Lee et al., 2002). Therefore, this study will analyze and discuss the present 25nm NAND Flash process, as well as furnace tube machine related process design review and proposal creation. At present, the main potential hazards in the 22nm NAND Flash process of Taiwan's 12" high-tech plants include dropping, rolling, falling, hitting, object falling, object crash, object collapse, being hit, being crimped, being rolled, being incised, being cut, trampling, trampling through, contacting high temperature, contacting low temperature, shocks, fires, explosions, poisoning, corrosion, radiation, burn and scald, object breakup, etc. The scenarios related of ISD strategies to the Flash process are as shown in Table 5. The inherently safer design strategies of intensification, substitution, attenuation, and limitation of effects can be considered first for the above potential hazards. When potential hazards cannot be effectively eliminated, the inherently safer design strategies of avoiding knock-on effects, simplification, making status clear, rendering incorrect assembly impossible, tolerance, ease of control, and software can be adopted in order to attenuate the effect of potential hazards.

According to the multi-level structure in Figure 9, a look-up table of NAND Flash process design component structures of ISD strategies and reacting substances are compiled, as shown in Table 6. It is observed that the process design most related to the furnace is the hard mask layer, well doping, $\mathrm{SiO} 2$ isolation dielectric layer, storage area and control gate poly, metal online dielectric layer, etc. This study will focus on the thin film process of a furnace for subsequent simulation and adjustment.

The present NAND Flash design specification requirements after applied ISD strategies of high-tech circles are integrated in Table 7. The minimum size is that the width of polysilicon storage area is 22nm, and the process is characterized by low operating voltage, multi-core I/O, semiconductive passive device, twin-well, self-aligned, gate tensile, and compressive stress layer. The process design must implement layout according to the design specification size with existing material characteristics. The layout components are minimized in order to maximize the number of components on a single wafer surface, and product capacity is maximized. On this principle, whether the existing material has high toxicity, high explosibility, or high reactivity, the intensification, substitution, and attenuation of inherently safer design strategies are used to create the processes of this design proposal. Table 8 shows the process design and adjustment proposal after applied ISD strategies, as created according to Table 7. Different reactive materials result in different component characteristics. Therefore, the original SiH4 is replaced by TEOS for process simulation in this study in order to observe whether the product features conform to the original design specification requirements.

\section{Research validation and discussion after applied ISD strategies}

The NAND Flash is produced layer by layer through the processes stated in Table 7. Therefore, the review of process design must start from product design. Figure 10 shows the dimensions that must be considered for metal online in the storage area of NAND Flash, including storage area width, operation area width, metal connecting wire width, metal connecting wire thickness, and metal connecting wire length. For example, the metal connecting wire length will influence current and impedance (I=V/R), and certainly will influence the component consumed power $(\mathrm{P}=\mathrm{IV})$, thus, it must be considered.

The design is simulated according to 22nm design specifications. First, the NAND Flash plane layout is simulated according to the above design specifications, and the result is as shown in Figure 11 (a). The 3D structure is simulated to ensure that product thickness meets the expected demand. The simulated 3D diagram is as shown in Figure 11 (b). The design simulation result must confirm that the size conforms to the 22nm design specifications. Figure 12 shows detailed size, where the width of the well shall not be smaller than $106 \mathrm{~nm}$, otherwise the subsequent process cannot effectively align the size, and this is the key point in confirmation.

When the structural simulation is completed, the voltage/current characteristic curve is simulated, and the result is as shown in Figure 13. It is observed that the current is $0.1 \mathrm{~mA}$ of component operation when the driving voltage is $0.5 \mathrm{~V}$. The action current has reached steady $1 \mathrm{~mA}$ when the driving voltage is higher than $0.7 \mathrm{~V}$. There is no significant difference in the driving current when the component drain supplies $0.1 \mathrm{~V}$ and $1.8 \mathrm{~V}$, and the operation conforms to the product specifications of NAND Flash on the existing market. In 
addition, the Bode Plot frequency response is used for simulation, as shown in Figure 14. The NAND Flash component structure is similar to CMOSFET, thus, it is simulated using different magnifications (N). The result shows that the amplifier gain $\mathrm{Q}$ (unit: $\mathrm{dB}$ ) at high frequency and load, as well as the transistor parasitic capacitance effect, occurs at low magnification ( $\mathrm{N}: 2.5)$ greater than $4 \mathrm{GHz}$, and high magnification (N: 7.5) shall exceed $1.5 \mathrm{GHz}$. The above coupling ratio is 0.7138 , and the major function of NAND Flash is storage, and free from amplification, thus, the frequency influence is slight and meets existing product requirements.

This study tested 16 batches of wafer cassettes using a furnace machine according to the above simulation results. Each batch had 25 wafers, and wafer surface defects were matched. The furnace process setting conditions after applied ISD strategies are as shown in Table 9, wherein Level (0) for the general TEOS standard process setting conditions; Level (-) for reducing the process temperature of 15乃 and reducing portion process conditions; Level (+) for increasing the process temperature of 15 乃 and increasing portion process conditions. Figure 15 shows the wafer surface defect matching after experimentation. This study found that wafer surface defect is directly related to process contamination control, and there is no significant impact on the reactive material change. The test results of product yield, DC property, frequency response, and peeling ability after applied ISD strategies, are as shown in Table 10. Semiconductor product yield will affect the subsequent IC packaging process costs, representing the poor yield will lead to a substantial increase in product cost; electrical characteristics of DC of the semiconductor element due to some small signal characteristics caused by unstable operation of the electrical characteristics, the more unstable element action likely to cause failure of the entire IC operation; frequency response was to ensure that small part of the signal characteristics of the semiconductor element the level of interference from other signals, the lower the level of interference is the more stable product; the final release was the stripping ability to confirm the stability of the structure of the layers of material, the structure is more difficult to peel off without damaging the product is the more long service life. According to the experimental results, product yield is increased from $83.88 \%$ before substitution to $84.25 \%$, as wafer surface defect is well controlled and the processes have no significant deviation. The DC property improvement is increased from $6.16 \%$ to $6.76 \%$, which may be due to the dense TEOS liquid vapor reaction. In addition, frequency response improvement is increased from $4.97 \%$ to $5.16 \%$, because the material is dense. Finally, peeling ability improvement is increased from $4.27 \%$ to $4.36 \%$, as the TEOS liquid vapor reaction is dense. Figure 16 shows the SEM result of this study.

According to the above validation results, using inherently safer design strategies from the angle of process design can obtain relatively safe levels, while meeting existing product specification requirements. In this study case, SiH4 is changed to TEOS for the process; in terms of the overall wafer products, under the product specification requirements, the more hazardous gaseous silicomethane is replaced by liquid TEOS, and even though both have potential hazards of fire, explosion, and poisoning, liquid is less likely to leak or diffuse than gas, thus, the potential hazards are reduced, rendering it inherently safer.

Regarding the process reactor, potential hazards may be eliminated at the beginning of the process design. However, when the ISD in the process reactor cannot effectively eliminate all potential hazards, the inherently safer design strategies of limiting effects, simplification, making status clear, making incorrect assembly impossible, tolerance, ease of control, and software, can be used for the overall machine and facility system, and the precautionary measures for process safety can be considered according to the SEMI-S2 semiconductor process equipment safety standards in Table 11, thus, effectively increasing overall plant safety level (Rock et al., 2006; Weiss, 2006).

\section{Conclusions and suggestions}

Taking the general view of plant facilities, cleanroom environment, process tools, and internal reactors in the high-tech industry, there are the hazards of high temperature, gas leaks, fires, explosions, electrical shocks, rolling and crimping, organic solvent poisoning, acid and alkali corrosion, hitting and cutting, etc. universally existing in the high-tech process characteristics. Then the experiences for semiconductor manufacturing processes in Taiwan were planning and complete civil construction first, and then followed regulatory limits to provide the maximum piping and equipment for process production line installed in facility area, unlike the 
general considerations of petrochemical industry planning program. Therefore, this study was to investigate the ISD substitution strategies, to discuss the product design review and adjustment process, replaced silane to more safe TEOS to achieve product specification requirement. The proposed configuration was for the first time applied in NAND flash component technology. There have been no similar schemes used before as in this study, and also the industry has little exploration in this way. It is an important outcome of this study.

The study found that the wafer surface defects were more directly related to process contamination control, compared with no significant effect on the reaction material change. According to the experimental results, the product yield increased from $83.88 \%$ of $\mathrm{SiH} 4$ to $84.25 \%$ of TEOS, as the wafer surface defect was well controlled and the various processes had no significant deviation. The DC property improvement increased from $6.16 \%$ to $6.76 \%$, which might be due to the dense reaction with TEOS liquid vapor. In addition, the frequency response improvement increased from $4.97 \%$ to $5.16 \%$, as the material was compact. Finally, the peeling ability improvement increased from $4.27 \%$ to $4.36 \%$, because the TEOS liquid vapor reaction was denser.

According to the above validation results, using ISD strategies from the perspective of process design could obtain relatively safer levels, while meeting the existing product specification requirements. In this study case, SiH4 was changed to TEOS for the process, in terms of the overall wafer products, under the product specification requirements, the more hazardous gaseous $\mathrm{SiH} 4$ was replaced by liquid TEOS, and even if both have potential hazards of fire, explosion, and poisoning, and the liquid was less likely to leak or diffuse than gas, thus, potential hazards were reduced, rendering it inherently safer.

The process conditions determine the configuration and characteristics of plant equipment construction. So, the starting point for safe design should begin from the process, shown in Fig 17. This idea is also similar to the core structure of Figure 1, from the beginning of the process design. The biggest difference is that this study should begin from the component structure to explore the application of ISD, and gradually out to the whole plant comprehensive application of ISD discussion, thus, effectively enhancing inherently safer level. Therefore, the following detailed suggestions were recommended as below:

(1) The process design shall begin at the plant planning stage, and inherently safer design strategies are implemented in the detailed design.

(2) A safety process proposal, which can adopt inherently safer design strategies of intensification, substitution, and attenuation, is determined from product design review, in order to adjust the process design.

(3) The process design adjustment shall consider potential hazard characteristics.

(4) Regarding hazards that cannot be eliminated through process design, the inherently safer design strategies of the limitation of effects, simplification, making status clear, making incorrect assembly impossible, tolerance, ease of control, and software, as well as SEMI-S2 semiconductor process equipment safety standards, are used to consider the precautionary measures of process safety.

(5) Finally, the process design is reviewed before the machine integrity is reviewed, and then facility system safety is reviewed.

\section{Acknowledgement}

Funding for this investigation was provided by National Science Foundation, Taiwan, ROC. Under grant number NSC 102-2622-E-238-008-CC3. 


\section{References}

Akkermans, H., Bogerd, P., \& Doremalen, J.V. (2004). Travail, transparency and trust: A case study of computer-supported collaborative supply chain planning in high-tech electronics. European Journal of Operational Research, 153(2), 445-456.

Chang, K. C., \& Chen, C. Y. (2007a). A study for inherently safer design and application on high-tech industrial. Industrial Safety Technology Quarterly, 63(6), 18-33.

Chang, K. C., \& Chen, C. Y. (2007b). Analysis of high-tech factory hazardous situations and study of joint defense and emergency response mechanism in high-tech parks. Industrial Safety Technology Quarterly, 64e06, 21-36.

Chen, C.Y., Chang, K.C., Huang, C.H., \& Lu, C.C. (2014). Study of chemical supply system of high-tech process using inherently safer design strategies in Taiwan. Journal of Loss Prevention in the Process Industries, 29, 72-84.

Chen, C.Y., Chang, K.C., Lu, C.C., \& Wang, G.B. (2013a). Study of high-tech process furnace using inherently safer design strategies (II). Deposited film thickness model. Journal of Loss Prevention in the Process Industries, 26, 225-235.

Chen, C.Y., Chang, K.C., \& Wang, G.B. (2013b). Study of high-tech process furnace using inherently safer design strategies (I) Temperature distribution model and process effect. Journal of Loss Prevention in the Process Industries, 26, 1198-1211.

Chen, F,. Koufaty, D.A., \& Zhang, X.D. (2009).Understanding intrinsic characteristics and system implications of flash memory based solid state drives. SIGMETRICS '09 Proceedings of the eleventh international joint conference on Measurement and modeling of computer systems, 181-192.

Desu, S. B. (1989). Decomposition chemistry of Tetraethoxysilane. Journal of the American Ceramic Society, 72(9), 1615.

Fujino, K., Nishimoto , Y., Tokumasu, N., \& Maeda, K. (1990). Silicon Dioxide Deposition by Atmospheric Pressure and Low $\exists$ emperature CVD Using TEOS and Ozone. J. Electrochem. Soc. 137(9), 2883-2887.

Gill, G.K., \& Shergill, G.S. (2004). Perceptions of safety management and safety culture in the aviation industry in New Zealand. Journal of Air Transport Management, 10(4), 231-237.

Granier, A., Vervloet, M., Aumaille, K., \& Vallie, C. (2003). Optical emission spectra of TEOS and HMDSO derived plasmas used for thin film deposition. Plasma Sources Sci. Technol, 12, 89.

Hong Xiao. (2012). Introduction to Semiconductor Manufacturing Technology (2nd ed.). Prentice Hall, ISBN-13: 978-0130224040.

Irom, F., Nguyen, D.N. (2007). Single Event Effect Characterization of High Density Commercial NAND and NOR Nonvolatile Flash Memories. Journal of IEEE Transactions on Nuclear Science, 54(6), 2547-2553.

Kang, J.U., Jo, H., Kim, J.S., \& Lee, J. (2006). A superblock-based flash translation layer for NAND flash memory. EMSOFT '06 Proceedings of the 6th ACM \& IEEE International conference on Embedded software, $161-170$. 
Katsumata, R., Kito, M., Fukuzumi, Y., Kido, M., Tanaka, H., Komori, Y., Ishiduki, M., Matsunami, J., Fujiwara, T., Nagata, Y., Zhang, L., Iwata, Y., Kirisawa, R., Aochi, H., Nitayama, A. (2009). Pipe-shaped BiCS flash memory with 16 stacked layers and multi-level-cell operation for ultra high density storage devices., 2009 Symposium on VLSI Technology Conference, 136 - 137.

Khan, F.I., \& Amyotte, P. (2002). Inherent safety in offshore oil and gas activities: a review of the present status and future directions. Journal of Loss Prevention in the Process Industries, 15(4), 279-289.

Khan, F. I., \& Amyotte, P. (2003). How to make inherent safety practice a reality. The Canadian Journal of Chemical Engineering, 81(1), 2-16.

Kletz, T. A. (1984). Cheaper, safer plants, or wealth and safety at work. Rugby, Warwickshire, England: The Institute of Chemical Engineers.

Kletz, T. A. (1985). Inherently safer plants. Plant/Operations Progress, 4(3), 164-167.

Kletz, T. A. (1998). Process plant: A handbook for inherently safer design. Taylor \& Francis.

Kwon, H.M. (2006). The effectiveness of process safety management (PSM) regulation for chemical industry in Korea). Journal of Loss Prevention in the Process Industries, 19(1), 13-16.

Lee, J.D., Hur, S.H., Choi, J.D. (2002). Effects of floating-gate interference on NAND flash memory cell operation. Journal of IEEE Electron Device Letters, 23(5), 264-266.

Leveson, N., Dulac, N., Marais, K., \& Carroll, J. (2009). Moving Beyond Normal Accidents and High Reliability Organizations: A Systems Approach to Safety in Complex Systems. Journal of Organization Studies, 30(2-3), 227-249.

Lu, C.C., Chang, K.C., \& Chen, C.Y. (2014). Study of High-tech Process Furnace using Inherently Safer Design Strategies (III) Advanced Thin Film Process and Reduction of Power Consumption Control. Submited to Journal of Loss Prevention in the Process Industries. (Under review)

Pole, Y. (2003). Development and applications of CASEHAT - a multipurpose computer aided hazard analysis automation system used in semiconductor manufacturing industry. Journal of Loss Prevention in the Process Industries, 16(4), 271-279.

Rasmussen, J. (1997). Risk management in a dynamic society: a modeling problem. Journal of Safety science, 27(2/3), 183-213.

Rock, M.T., Lim, P.L., \& Angel, D.P. (2006). Impact of Firm-Based Environmental Standards on Subsidiaries and Their Suppliers: Evidence from Motorola-Penang. Journal of Industrial Ecology, 10(1-2), 257-278.

Sze, S. M., \& Ng, K. K. (2006). Physics of semiconductor devices (3rd ed.). Wiley, ISBN 978-0-471-14323-9.

Tay, K.M., Lim, C.P. (2006). Fuzzy FMEA with a guided rules reduction system for prioritization of failures. International Journal of Quality \& Reliability Management, 23(8), 1047 - 1066.

Trammell, S.R., Davis, B.J.(2001). Using a modified Hazop/FMEA methodology for assessing system risk. Proceedings. 2nd International Workshop on Engineering Management for Applied Technology Conference, $47-53$. 
Tsai, B.H., \& Lin, Y.Y. (2014). The Application of Diffusion Model in the Analysis of Location and Sales Distributions for the Semiconductor Industry. Journal of Commerce and Strategy, 6(3), 167-180.

Weiss, B. (2006).The SEMI International Standards Program - History, Successes and Lessons Learned to Address Compound Semiconductor Manufacturing Challenges. CS MANTECH Conference, 24-27.

Whitcomb, R., Rioux, M.(1994). Failure modes and effects analysis (FMEA) system deployment in a semiconductor manufacturing environment. Advanced Semiconductor Manufacturing Conference and Workshop, 136 - 139.

@ 


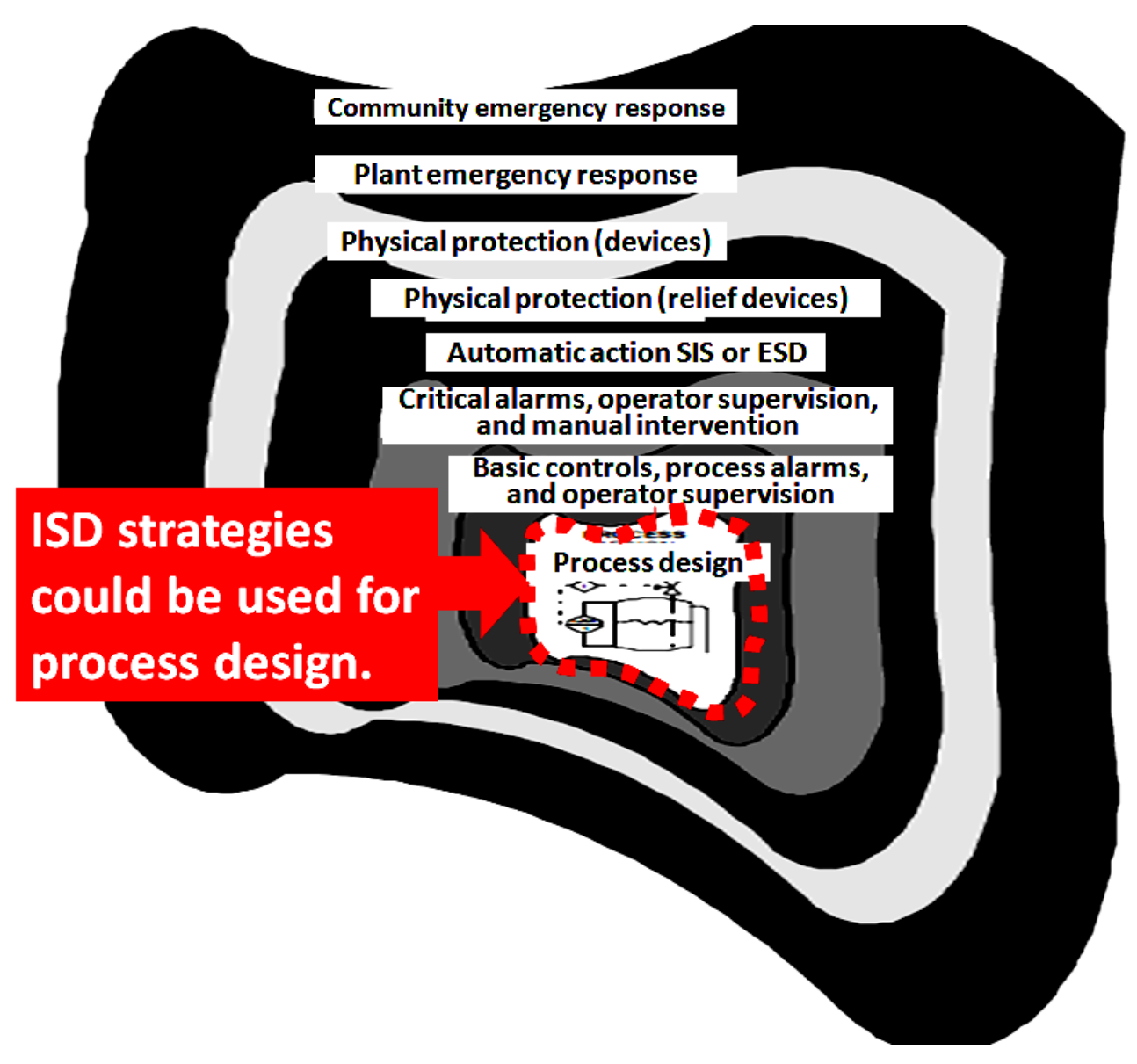

Figure. 1. ISDstrategies application in chemical process and plant 
Prevent fire area dash

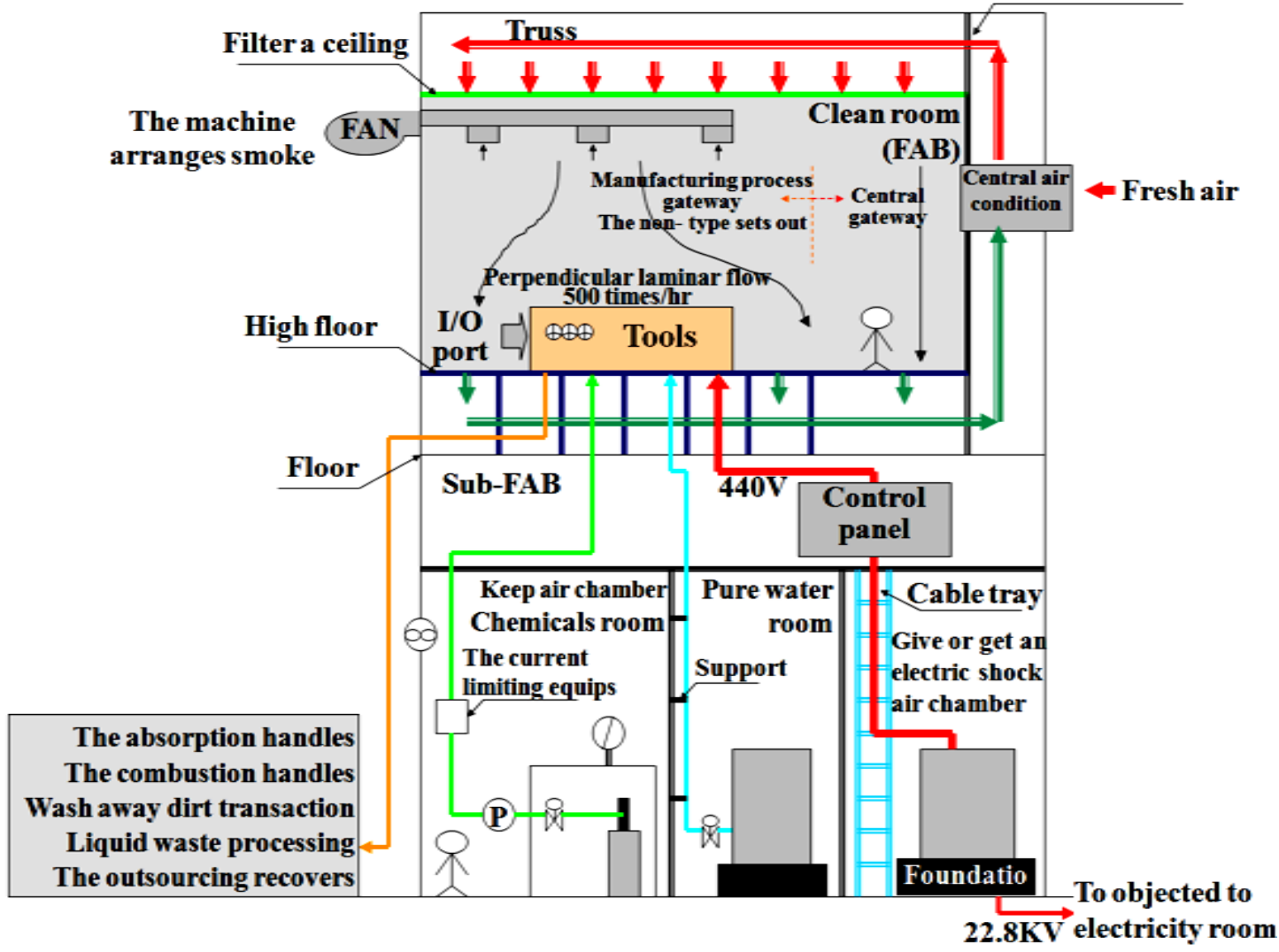

Figure. 2. Relationship diagram of high-tech factory process equipment and factory supply systems

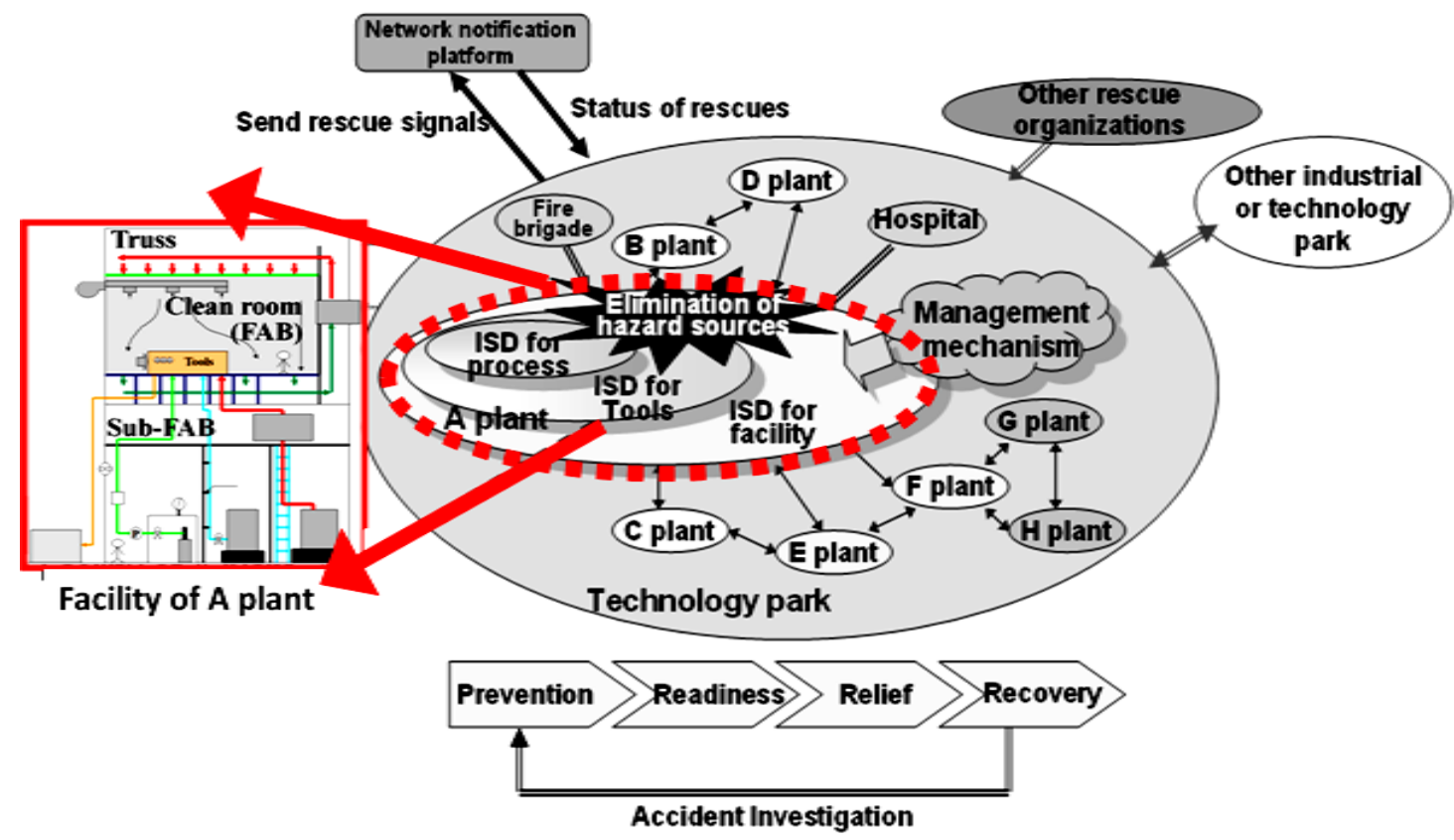

Figure. 3. Structural diagram of the application of ISD strategies in a high-tech park 


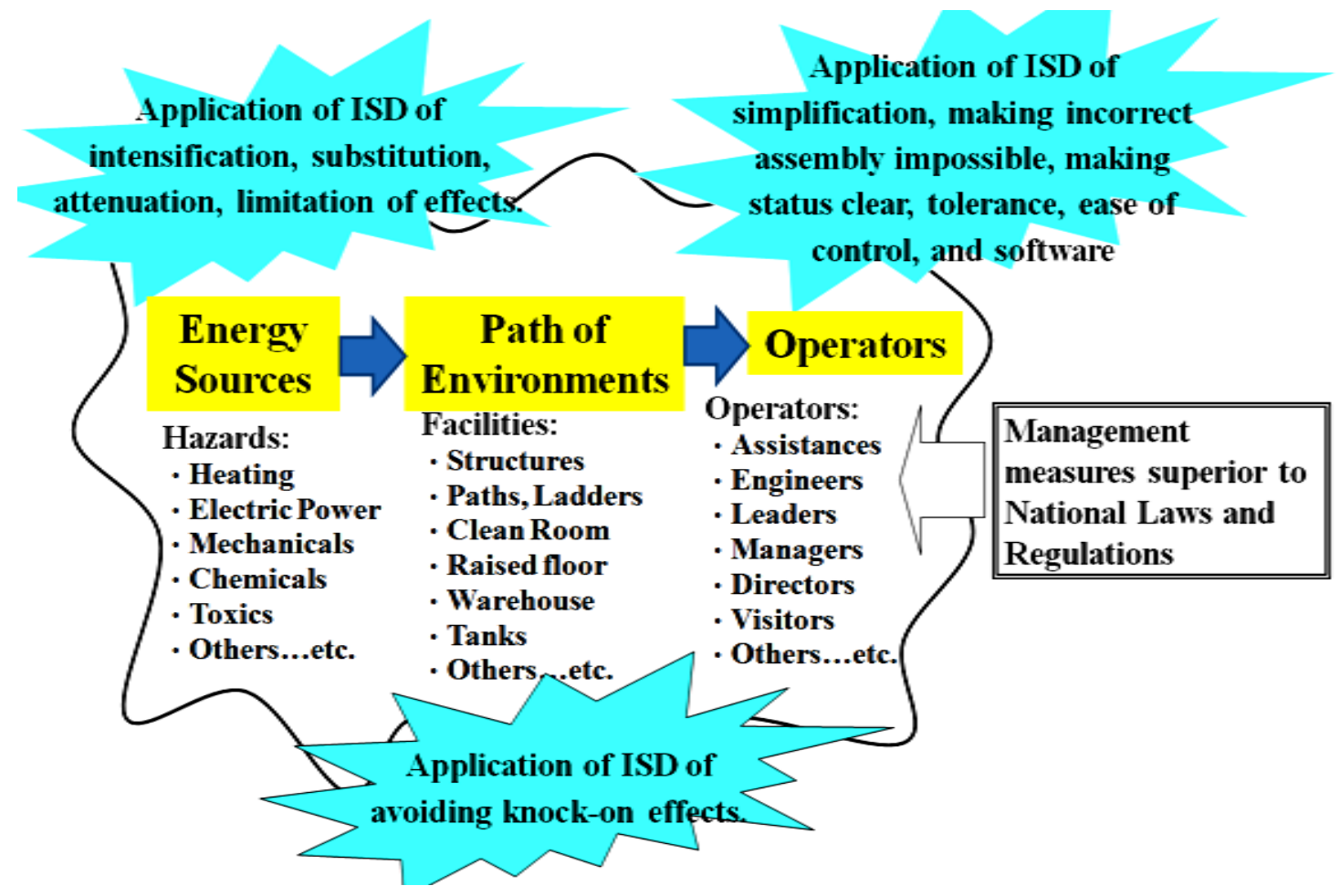

Figure. 4. ISD strategiesapplication in high-techplantmechanism

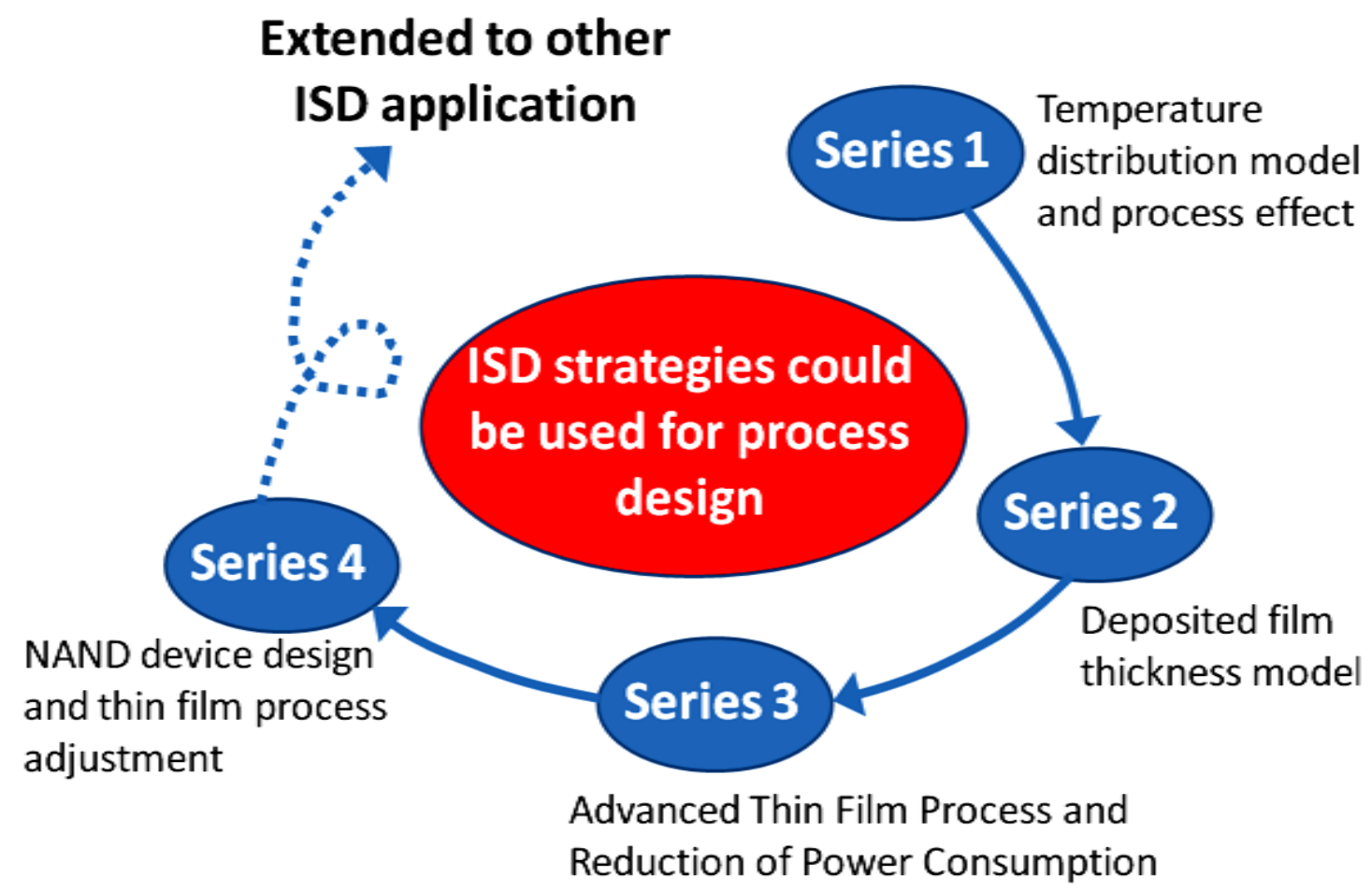

Figure. 5.ISD strategiesfocused ina series of author studies 

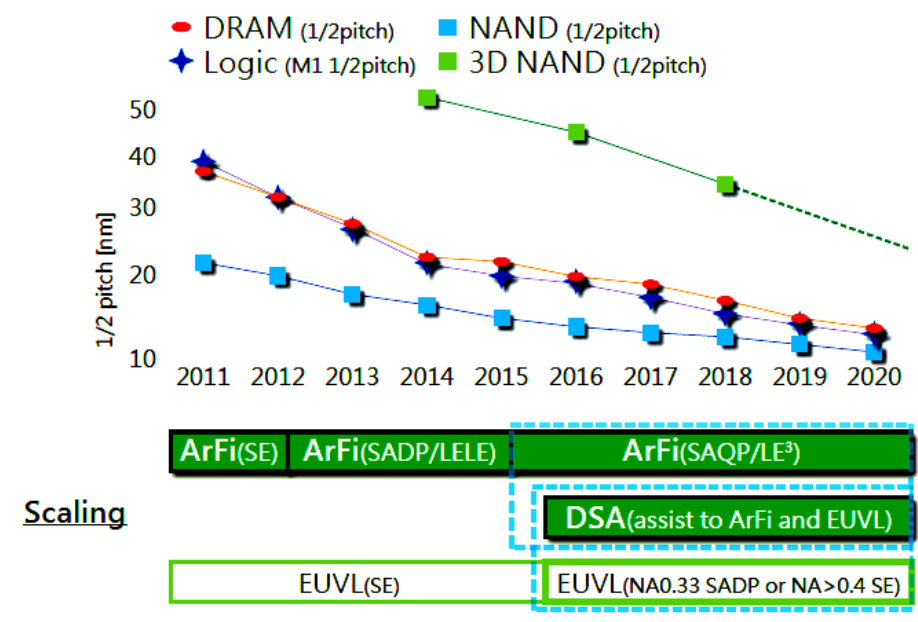

Wafer Size Increase

Integration

\begin{tabular}{|c|c|}
\hline $450 \mathrm{~mm}$ & $450 \mathrm{~mm}$ \\
\hline 3D NAND, TSV etc \\
\hline
\end{tabular}

Figure.6. Dimensions development trends of semiconductor photolithography process

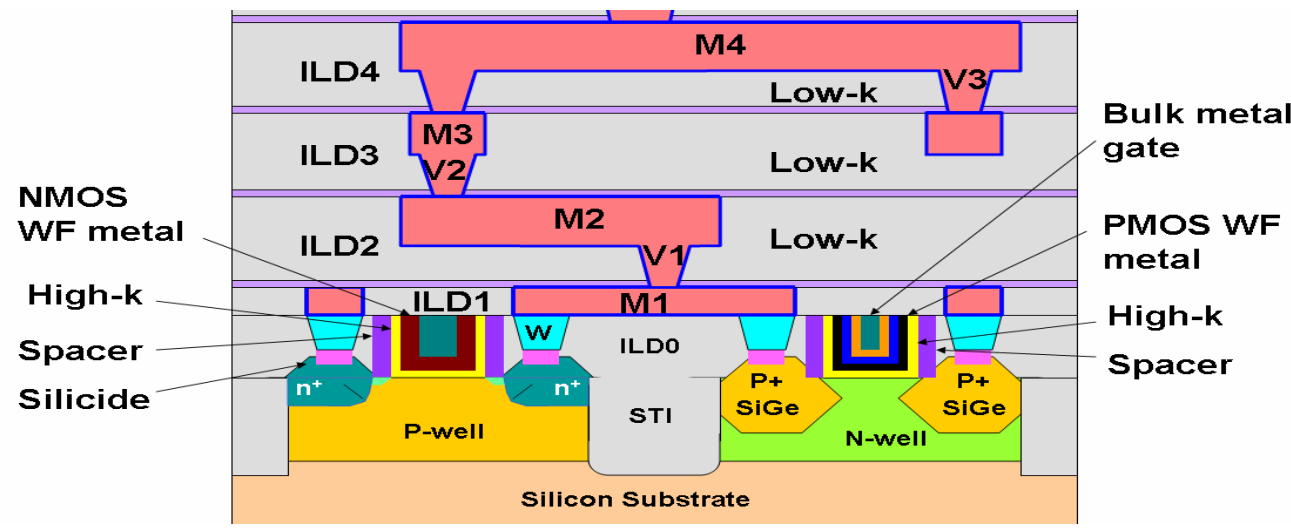

Figure.7. Advanced LogicProduct Architecture of 22nm IC 
Research supplement

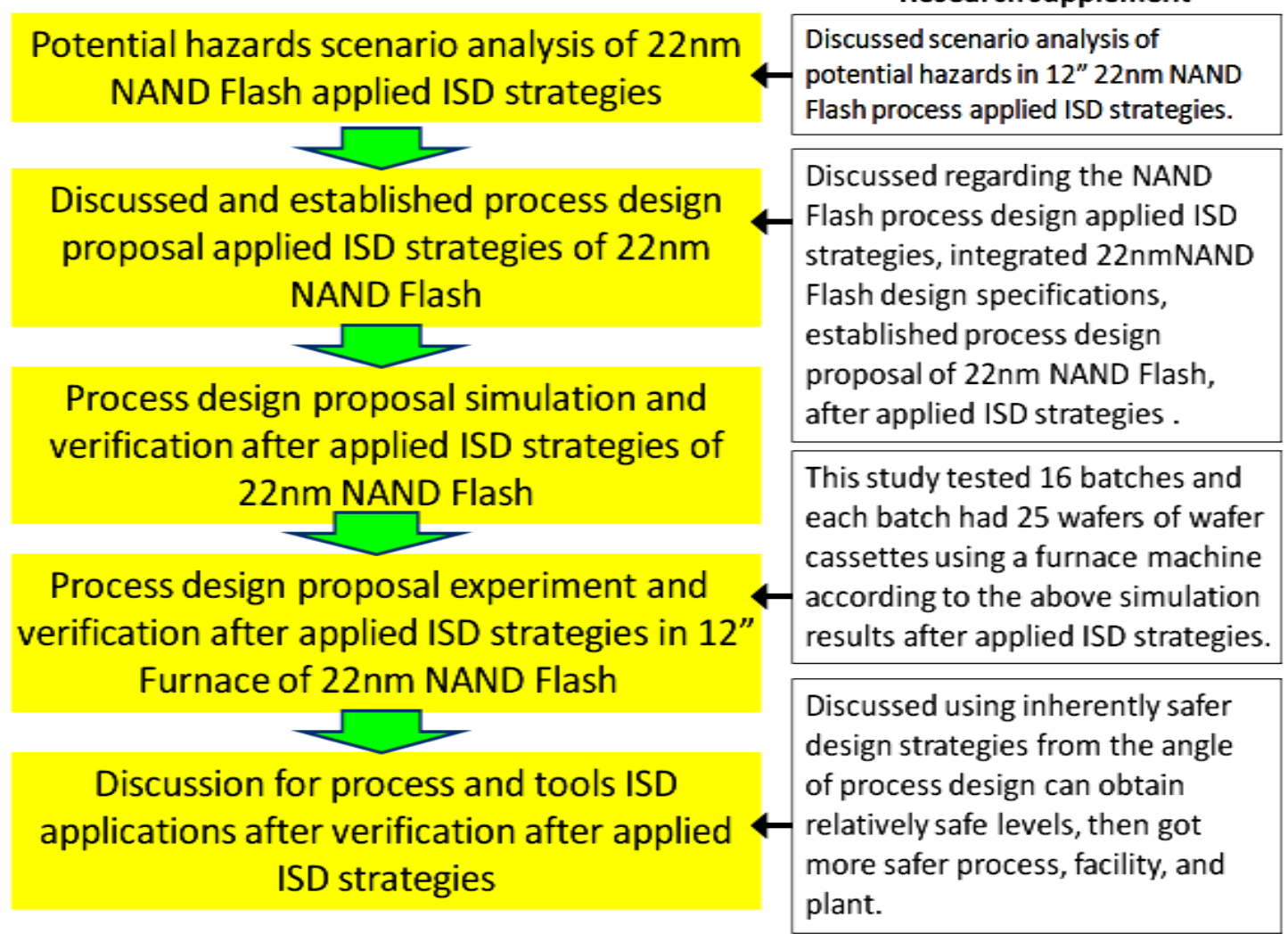

Figure.8. Research method and procedure in this study 


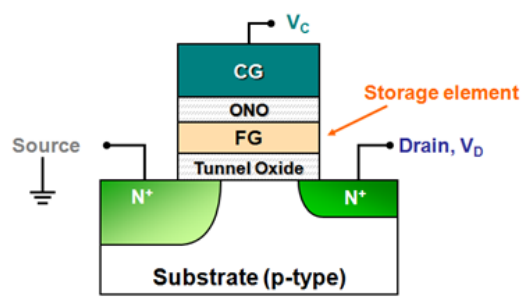

(a) Single-layer structure of NAND Flash

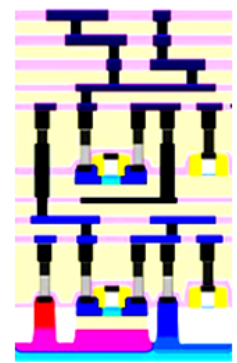

(b) Multi-layer structure of NAND Flash

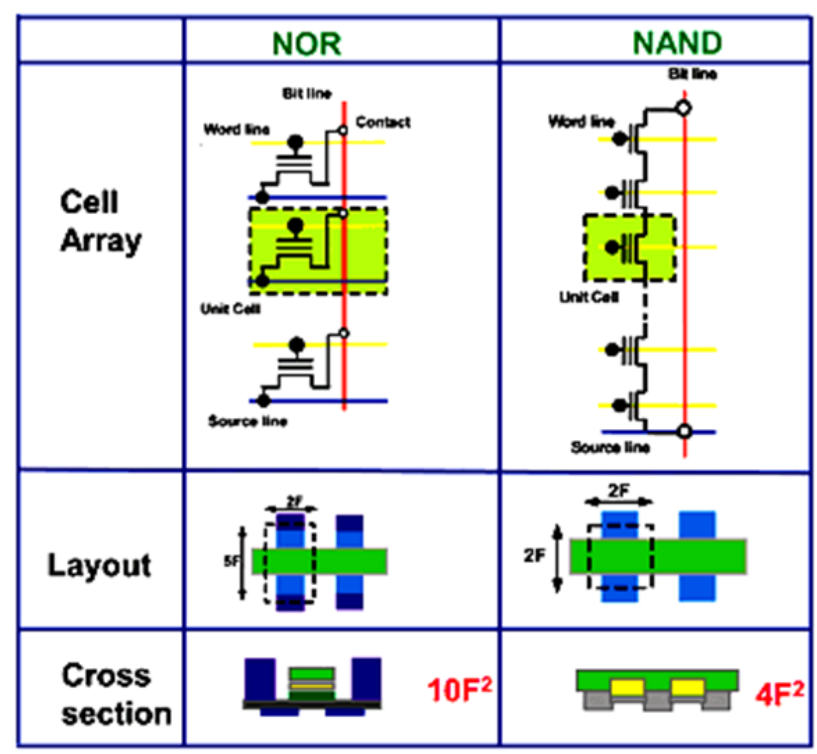

(c) Compared for NAND Flash and NOR Flash

Figure.9. Compared the storage structure of Flash

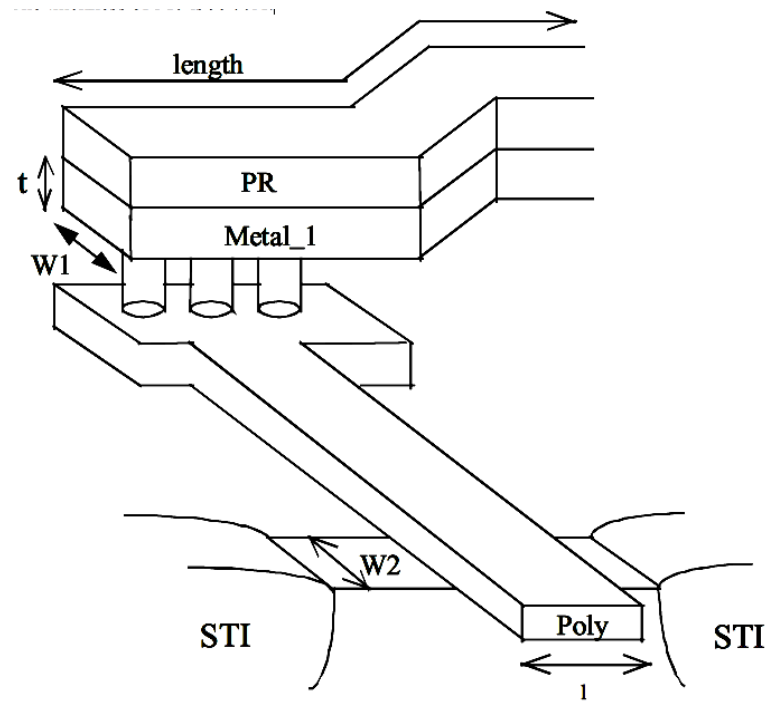

Figure.10. Schematic of metal online in NAND Flash storage area 


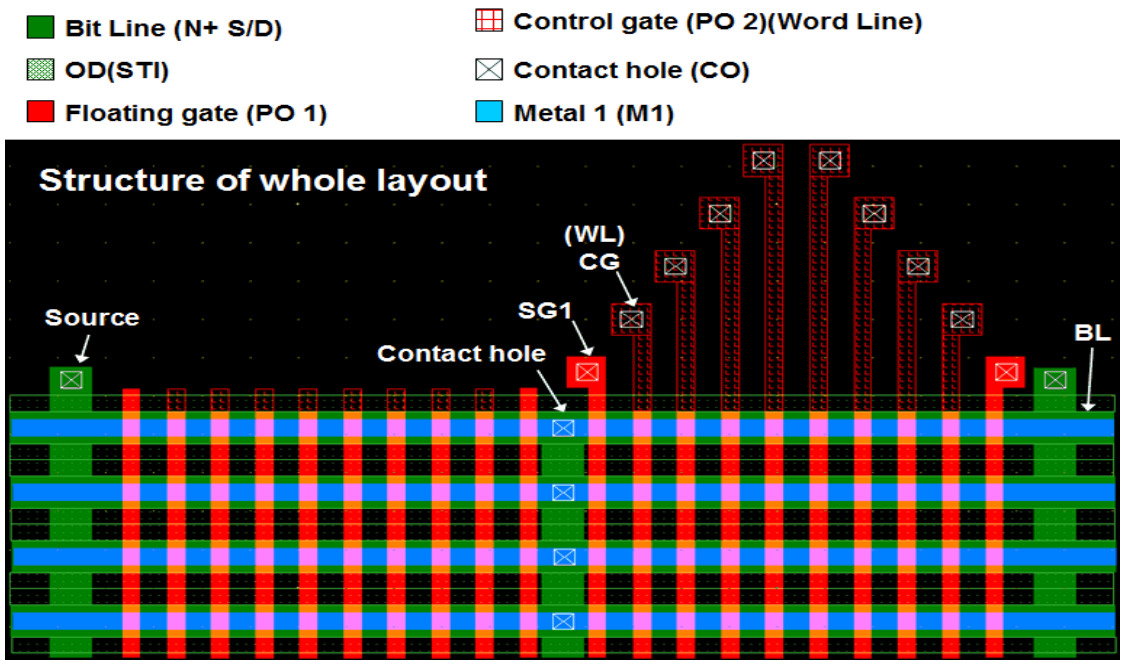

(a) Layout Simulation

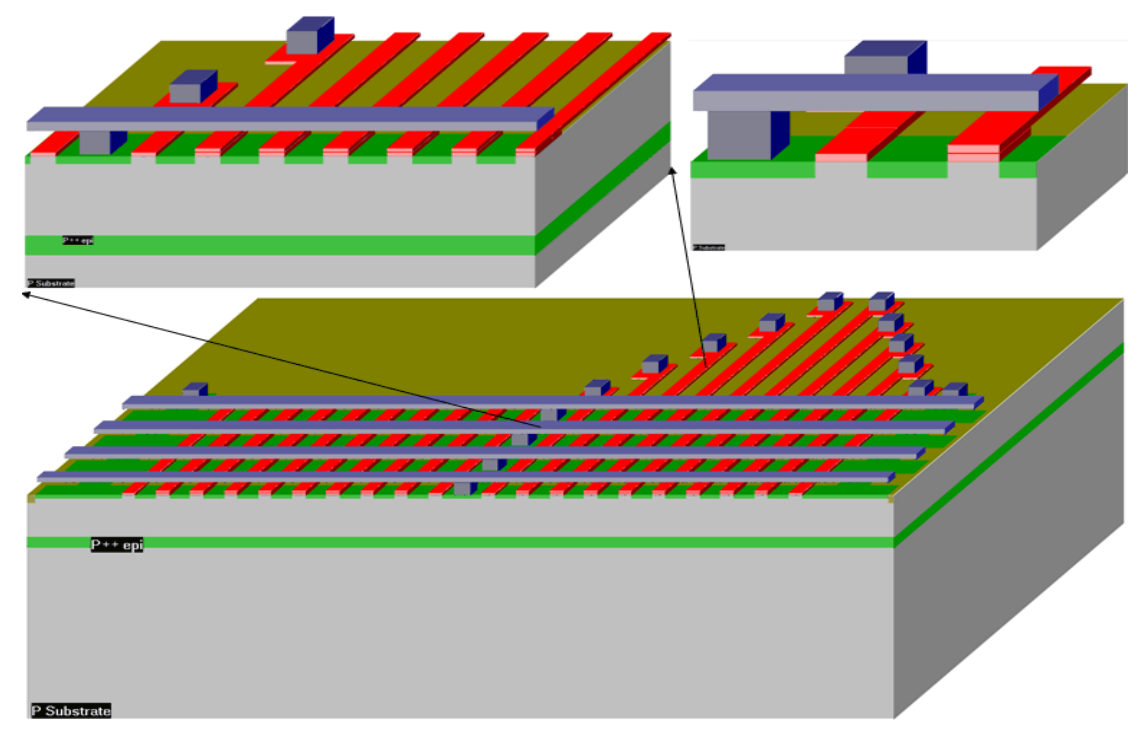

(b)Simulated 3D Structure

Figure.11. Simulation Results of 22nmNAND Flash 


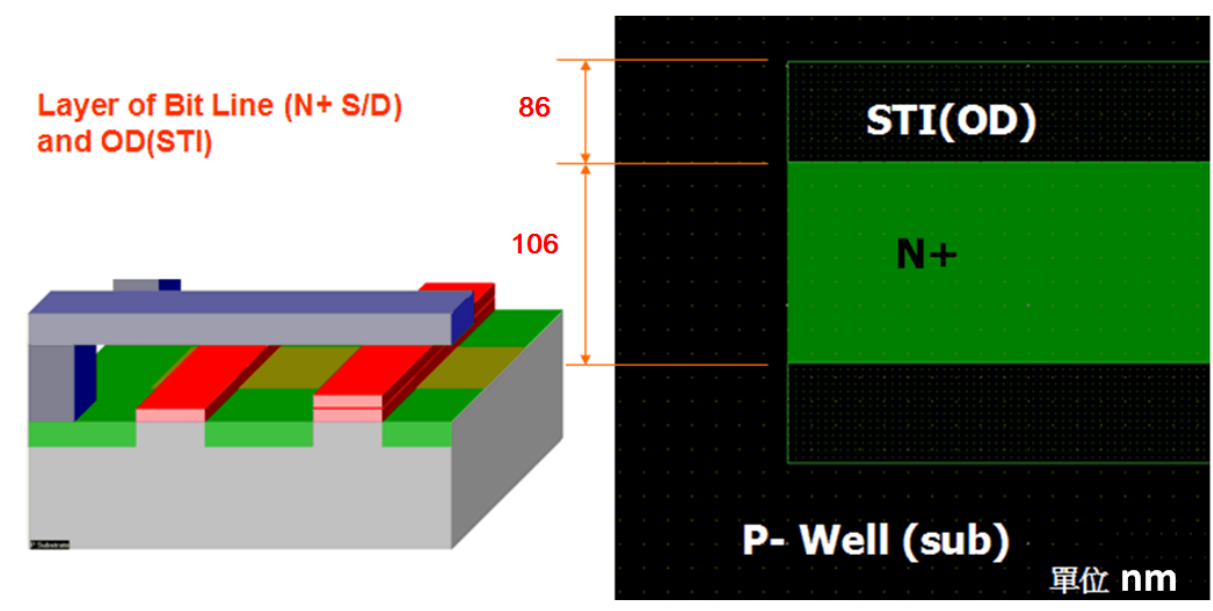

Figure.12. Confirmation of 22nmNAND Flash detailed size

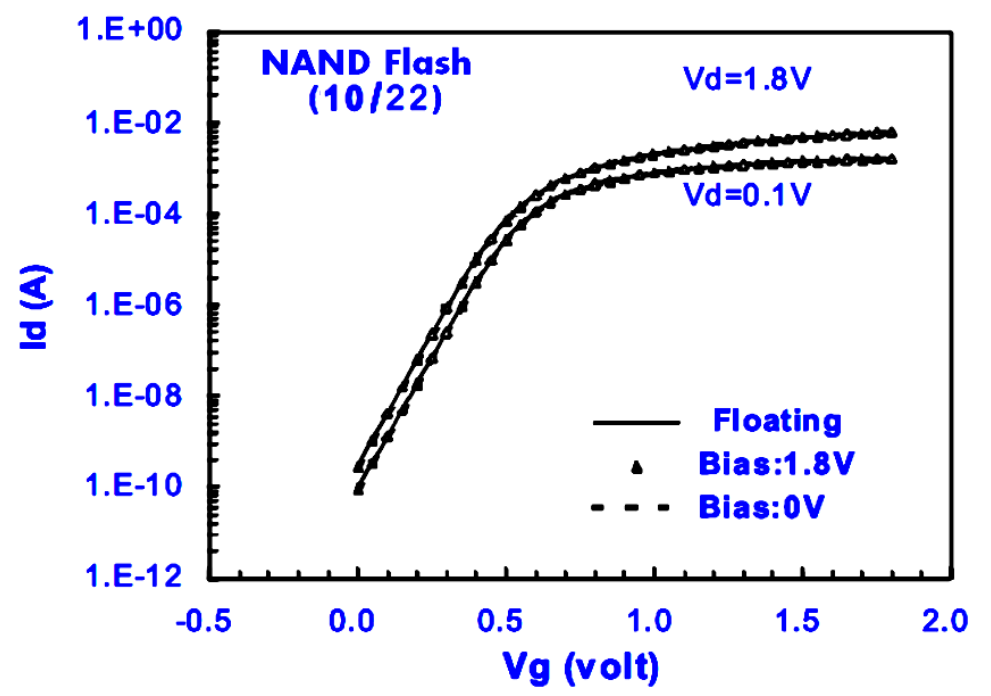

Figure. 13. Voltage/current characteristic curve simulation result 


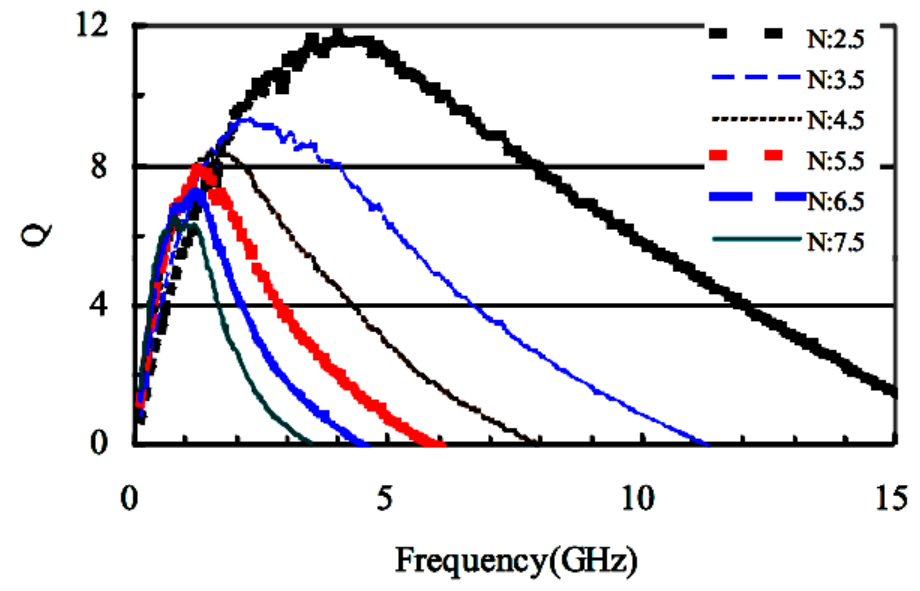

Figure. 14. Frequency response simulation result
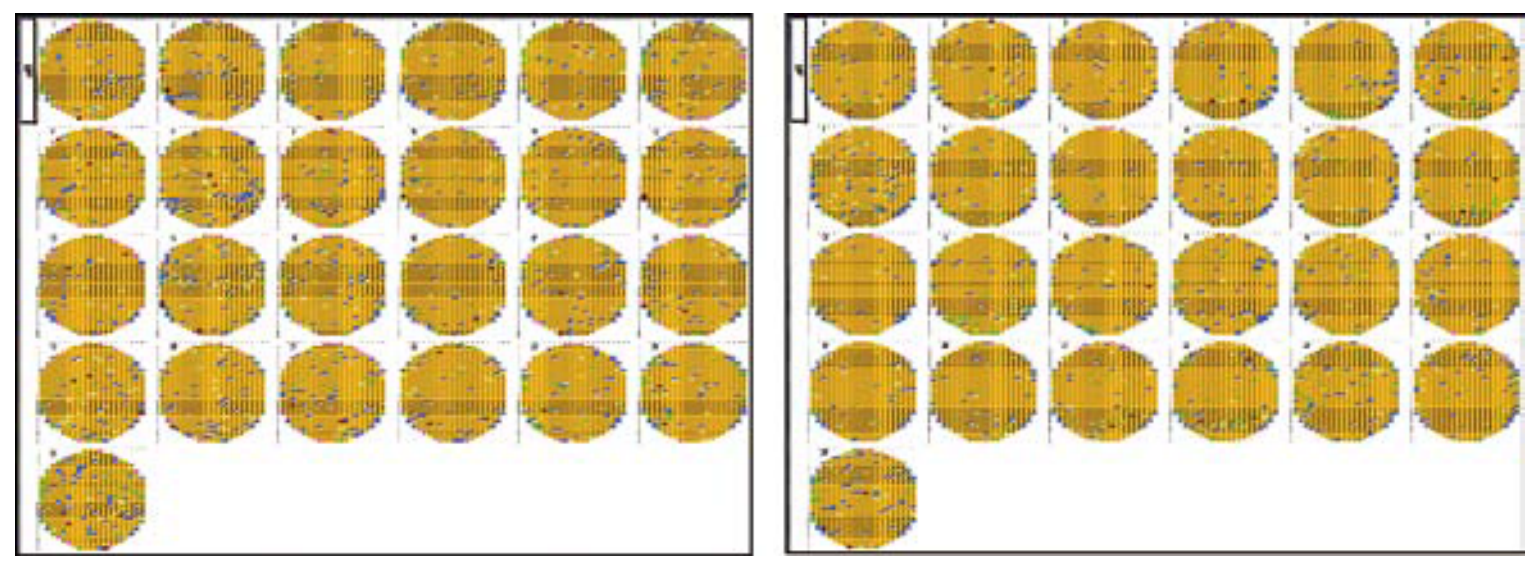

Figure. 15. Matching of surface defects in various batches of wafers 


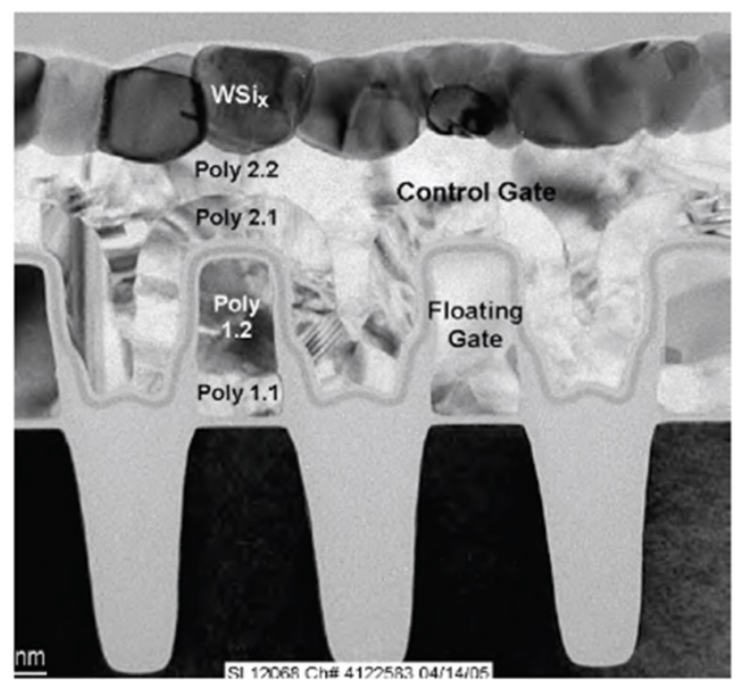

Figure. 16. SEM result of this study

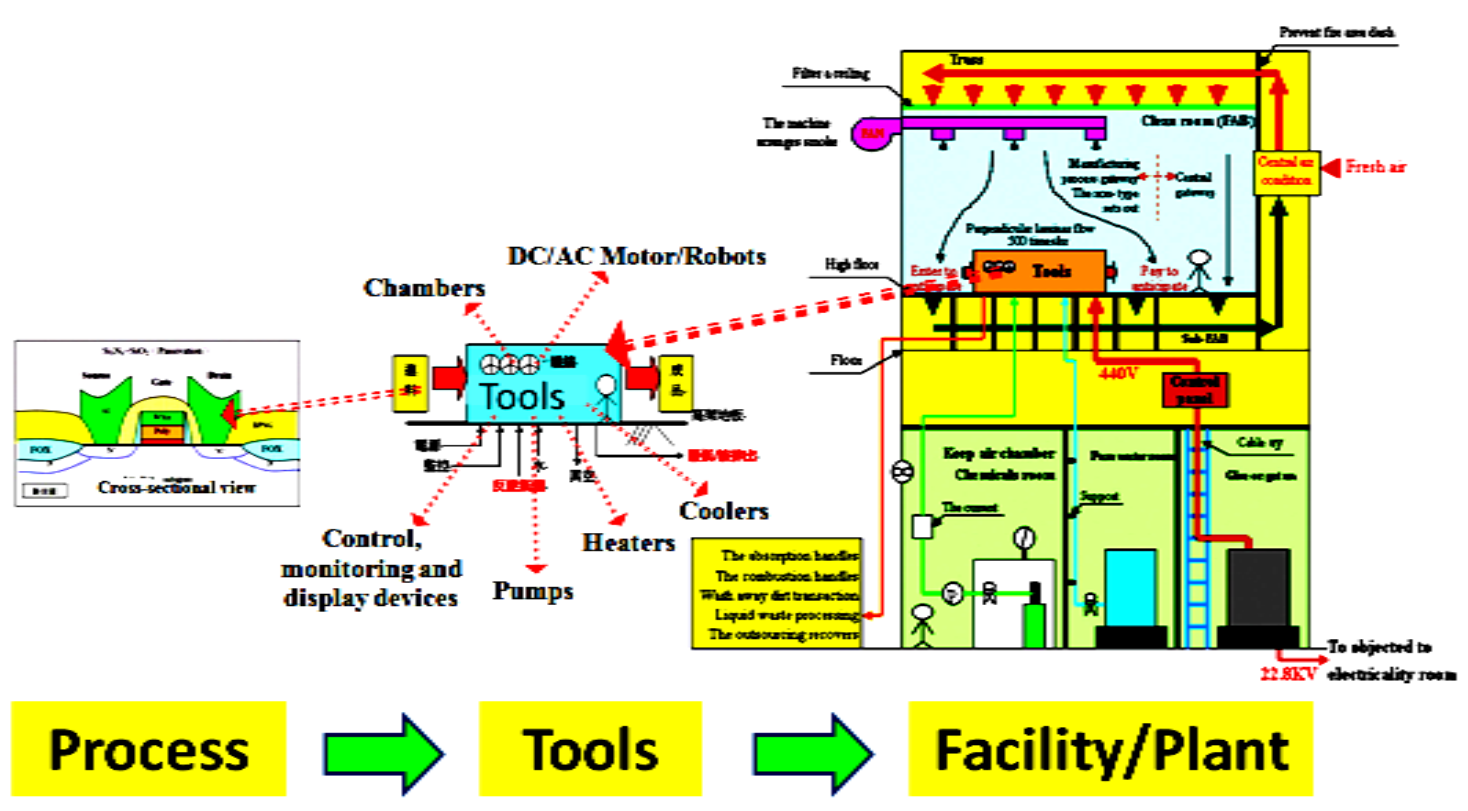

Figure. 17. Suggested ISD application structure of high-tech plant 
Table 1 Analysis hazards in advanced 22nm IC process, equipment, and facility system

\begin{tabular}{|c|c|c|}
\hline Process stage & Equipment structure & Potential hazard \\
\hline Crystal block growth & $\begin{array}{l}\text { Structure, heat sink, pressure gauge, control valve, } \\
\text { motor, tubing, wiring, monitoring }\end{array}$ & $\begin{array}{l}\text { High temperature, toxic gas leak, } \\
\text { fires, explosions, shocks, rolling } \\
\text { and crimping }\end{array}$ \\
\hline Wafer cutting & $\begin{array}{l}\text { Reactor, display screen, control panel, driving } \\
\text { device, casing structure, grinding wheel, wire } \\
\text { cutting unit structure, tubing, wiring, monitoring }\end{array}$ & $\begin{array}{l}\text { Organic solvent poisoning, acid } \\
\text { and alkali corrosion, shocks, } \\
\text { rolling and crimping, hitting, } \\
\text { cutting }\end{array}$ \\
\hline $\begin{array}{l}\text { Oxidation and heat } \\
\text { treatment }\end{array}$ & $\begin{array}{l}\text { Wafer transport unit, structure, heat sinking, air } \\
\text { filtration, heater, power supply, tubing, wiring, } \\
\text { monitoring }\end{array}$ & $\begin{array}{l}\text { High temperature, fires, } \\
\text { explosions, shocks, crimping }\end{array}$ \\
\hline Diffi & $\begin{array}{l}\text { Wafer transport unit, structure, heat sinking, air } \\
\text { filtration, heater, power supply, tubing, wiring, } \\
\text { monitoring }\end{array}$ & $\begin{array}{l}\text { High temperature, leak poisoning, } \\
\text { fires, explosions, shocks, crimping }\end{array}$ \\
\hline PVD & $\begin{array}{l}\text { Wafer transport unit, reactor, power supply, } \\
\text { isolating valve, cryogenic valve, mechanical } \\
\text { pump, tubing, wiring, monitoring }\end{array}$ & $\begin{array}{l}\text { High temperature, leak poisoning, } \\
\text { fires, explosions, shocks, } \\
\text { crimping, rolling }\end{array}$ \\
\hline CVD & $\begin{array}{l}\text { Wafer transport unit, reactor, controller, reacting } \\
\text { gas supply line, vacuum system, earthed system, } \\
\text { tubing, wiring, monitoring }\end{array}$ & $\begin{array}{l}\text { High temperature, leak poisoning, } \\
\text { corrosion, fires, explosions, } \\
\text { shocks, crimping }\end{array}$ \\
\hline Lithography & $\begin{array}{l}\text { Wafer transport unit, spin coating chamber, } \\
\text { photoresist spray coating, mechanical arm, } \\
\text { vacuum system, equipment structure, grounding, } \\
\text { rotator, soft baking machine, tubing, wiring, } \\
\text { monitoring }\end{array}$ & $\begin{array}{l}\text { High temperature, leak poisoning, } \\
\text { corrosion, fires, explosions, } \\
\text { shocks, rolling and crimping }\end{array}$ \\
\hline Etching & $\begin{array}{l}\text { Wafer transport unit, reactor, plate electrode, } \\
\text { crystal cup, coil magnet, vacuum unit, RF } \\
\text { generator, gas control and supply, grounding, } \\
\text { cooling water system, tubing, wiring, monitoring }\end{array}$ & $\begin{array}{l}\text { High temperature, leak poisoning, } \\
\text { corrosion, fires, explosions, } \\
\text { shocks, crimping, radiation }\end{array}$ \\
\hline Ion implantation & $\begin{array}{l}\text { Wafer transport unit, equipment structure, ion } \\
\text { source device, filter, analytic pore, 4-pole } \\
\text { focalizer, electrostatic beam deflector, scanner, } \\
\text { magnetic mirror, accelerator, crystal cup, Faraday } \\
\text { cup, cryopump, grounding, cooling water system, } \\
\text { tubing, wiring, monitoring }\end{array}$ & $\begin{array}{l}\text { High temperature, leak poisoning, } \\
\text { corrosion, fires, explosions, } \\
\text { shocks, crimping, radiation }\end{array}$ \\
\hline
\end{tabular}




\begin{tabular}{|c|c|c|}
\hline $\begin{array}{l}\text { Chemical } \\
\text { mechanical polishing } \\
\text { method }\end{array}$ & $\begin{array}{l}\text { Wafer transport unit, grinding unit, mechanical } \\
\text { device, polishing station device, brushing device, } \\
\text { unit structure, tubing, wiring, monitoring }\end{array}$ & $\begin{array}{l}\text { Leak poisoning, corrosion, fires, } \\
\text { explosions, shocks, crimping }\end{array}$ \\
\hline $\begin{array}{l}\text { Cleaning process } \\
\text { equipment }\end{array}$ & $\begin{array}{l}\text { Wafer transport unit, purge chamber, vehicle } \\
\text { transfer, steam dryer, mechanical arm, unit } \\
\text { structure, tubing, wiring, monitoring }\end{array}$ & $\begin{array}{l}\text { Leak poisoning, corrosion, fires, } \\
\text { explosions, shocks, crimping, } \\
\text { radiation }\end{array}$ \\
\hline Assembly process & $\begin{array}{l}\text { Wafer table, wafer output mechanism, vision lens } \\
\text { assembly, ejection mechanism, lead frame, lead } \\
\text { frame transport mechanism, gluing mechanism, } \\
\text { loading/unloading mechanism, lead frame output } \\
\text { mechanism, unit structure, tubing, wiring, } \\
\text { monitoring }\end{array}$ & $\begin{array}{l}\text { Leak poisoning, high temperature, } \\
\text { corrosion, fires, explosions, } \\
\text { shocks, crimping, rolling, hitting, } \\
\text { collapse }\end{array}$ \\
\hline Facility system & $\begin{array}{l}\text { Cleanroom, office, original material warehouse, } \\
\text { channel, chemicals room, electrical room, } \\
\text { ventilation equipment, pipeline support, outdoor } \\
\text { storage tank, wastewater disposal facility }\end{array}$ & $\begin{array}{l}\text { High temperature, corrosion, fires, } \\
\text { explosions, shocks, crimping, } \\
\text { rolling, hitting, collapse, } \\
\text { drowning, anoxia }\end{array}$ \\
\hline
\end{tabular}

Table 2 Summary the previous studies of high-tech process furnace using ISD strategies

\begin{tabular}{|c|c|}
\hline Series Title & Research contents \\
\hline $\begin{array}{l}\text { Temperature } \\
\text { distribution } \\
\text { model and } \\
\text { process effect }\end{array}$ & $\begin{array}{l}\text { 1. This study used the existing model of the horizontal furnace } \\
\text { to develop a simulation program. } \\
\text { 2. The simulation results were consistent with the existing } \\
\text { model, and produced even slightly better results on } \\
\text { temperature distribution and temperature sensitivity. } \\
\text { 3. The simulation model applied on a vertical furnace could } \\
\text { provide data on furnace temperature control for industrial use. } \\
\text { 4. Meanwhile, this study also deduced actual temperature } \\
\text { control and an ISD strategy, which are consistent with design } \\
\text { strategy principles. }\end{array}$ \\
\hline $\begin{array}{l}\text { Deposited film } \\
\text { thickness model }\end{array}$ & $\begin{array}{l}\text { 1. This study validated four types of process conditions, and } \\
\text { found that the results were very close to the experimental } \\
\text { values in the previous studies, when conditions such as } \\
\text { temperature, Mole fraction of silane, flow rate and pressure in } \\
\text { the process were changed. } \\
\text { 2. This study thus concluded that the proposed process film }\end{array}$ \\
\hline
\end{tabular}




\begin{tabular}{|c|c|}
\hline & $\begin{array}{l}\text { thickness mode could meet the requirement of the process } \\
\text { capacity. } \\
\text { 3. This study found that adjusting the heating zone temperature } \\
\text { to regulate the film thickness growth rate was able to control } \\
\text { uniformity of the film thickness. }\end{array}$ \\
\hline $\begin{array}{l}\text { Advanced Thin } \\
\text { Film Process and } \\
\text { Reduction of } \\
\text { Power }\end{array}$ & $\begin{array}{l}\text { 1. The adopted LPCVD reactor was of the commercial batch } \\
\text { type; the process experiments simulated the IPD process } \\
\text { applied on the } 22 \mathrm{~nm} \text { MOSFET, with a thickness of } 5000 \AA \\
\text { and process time of } 60 \mathrm{~min} .\end{array}$ \\
\hline Consumption & $\begin{array}{l}\text { 2. In the process of the first batch, as there were only } 100 \\
\text { wafers, the } 5^{\text {th }} \text { heating zone was shut off, thus, } 18.05 \mathrm{~A} \text { was } \\
\text { reduced by shutting off the } 5^{\text {th }} \text { heating zone. The machine had } \\
\text { a voltage of } 220 \mathrm{~V} \text { and converted power output up to } 3971 \mathrm{~W} \text {, } \\
\text { accounting for } 26 \%(15265.8 \mathrm{~W}) \text { of the entire machine. } \\
\text { 3. This significantly reduced power supply of the entire machine } \\
\text { and hazard potential, which is consistent with the } \\
\text { characteristics of inherently safer design. }\end{array}$ \\
\hline
\end{tabular}

Table 3 Comparison of physical, chemical and main hazardous properties between Silane and TEOS

\begin{tabular}{|l|l|l|}
\hline & \multicolumn{1}{|c|}{ Silane } & \multicolumn{1}{c|}{ TEOS } \\
\hline Appearance & Colorless & colorless \\
\hline Physical State & Gases & Liquid \\
\hline Molecular Weight & $32.117 \mathrm{~g} / \mathrm{mol}$ & $208.37 \mathrm{~g} / \mathrm{mol}$ \\
\hline Chemical Formula & $\mathrm{SiH}_{4}$ & $\mathrm{Si}\left(\mathrm{OC}_{2} \mathrm{H}_{5}\right)_{4}$ \\
\hline Odor & musty or pungent & $\begin{array}{l}\text { Sweet odor detectable at } 85 \\
\text { ppm }\end{array}$ \\
\hline Specific Gravity & $1.12 @ 25^{\circ} \mathrm{C}$ & 0.934 @ 20 ${ }^{\circ} \mathrm{C}$ \\
\hline Solubility in Water & Reacts slowly & $\begin{array}{l}\text { reacts with water, soluble in } \\
\text { ethanol, and 2-propanol }\end{array}$ \\
\hline pH & Not applicable & Not Applicable \\
\hline Boling Point & -111.5 & $168^{\circ} \mathrm{C}$ \\
\hline Melting Point & $-186{ }^{\circ} \mathrm{C}$ & $-82^{\circ} \mathrm{C}$ \\
\hline Vapor Pressure & $781 \mathrm{~mm} \mathrm{Hg} \mathrm{at}-111.9^{\circ} \mathrm{C}$ & $1 \mathrm{mmHg}$ \\
\hline Vapor Density (air $=$ & Not applicable & 7.22 \\
\hline
\end{tabular}




\begin{tabular}{|l|l|l|}
\hline 1.0$)$ & & \\
\hline Relative gas density & 1.1 & Not applicable \\
\hline Main Hazardous & $\begin{array}{l}\text { Extremely flammable, } \\
\text { pyrophoric in air }\end{array}$ & $\begin{array}{l}\text { Flammable, Harmful by } \\
\text { inhalation }\end{array}$ \\
\hline$\%$ Volatile & Not applicable & 99.9 \\
\hline Flash Point & $\begin{array}{l}\text { Not applicable, pyrophoric } \\
\text { gas }\end{array}$ & $105^{\circ} \mathrm{F}\left(40^{\circ} \mathrm{C}\right)$ \\
\hline Explosion limits & $1-100$ vol \% Pyrophoric. & $1.3-23$ vol \% \\
\hline $\begin{array}{l}\text { Auto-ignition } \\
\text { temperature }\end{array}$ & $18^{\circ} \mathrm{C}\left(64^{\circ} \mathrm{F} ; 291 \mathrm{~K}\right)$ & Not applicable \\
\hline
\end{tabular}

Table 4 LPCVD reactor conditions

\begin{tabular}{|c|c|}
\hline Condition & Unit \\
\hline Inlet gas flow rate : TEOS & $380 \mathrm{sccm}$ \\
\hline Pressure & 0.6 Torr \\
\hline Tube diameter & $435 \mathrm{~mm}$ \\
\hline Wafer diameter & $300 \mathrm{~mm}$ \\
\hline Tube length & $1215 \mathrm{~mm}$ \\
\hline Rotation rate & $2 \mathrm{rpm}$ \\
\hline Deposition time & $24.2 \mathrm{~min}$ \\
\hline Wafer & $125 \mathrm{wafers}^{\text {th }}$ \\
\hline Side Dummy : Top & $16^{\text {th }}$ \\
\hline Side Dummy : Bottom & \\
\hline
\end{tabular}




\begin{tabular}{|c|c|}
\hline Monitor & 3 wafers \\
\hline Capacity & 148 wafers \\
\hline
\end{tabular}

Table 5 Scenario analysis of potential hazards of ISD strategies in Taiwan's 12" 22nm NAND Flash process

\begin{tabular}{|c|c|c|}
\hline Potential hazard & Scenario analysis & Correlation with process design of ISD \\
\hline $\begin{array}{l}\text { Contacting } \\
\text { high/low } \\
\text { temperature }\end{array}$ & $\begin{array}{l}\text { Heaters and coolers are common process } \\
\text { condition control devices in high-tech } \\
\text { processes, thus, the equipments are likely to } \\
\text { have high/low temperature hazard. }\end{array}$ & $\begin{array}{l}\text { Product component design can be } \\
\text { improved, and process condition control } \\
\text { difficulty can be improved by using less } \\
\text { hazardous original material, further } \\
\text { reducing the hazardous energy of high/low } \\
\text { temperature. }\end{array}$ \\
\hline Shocks & $\begin{array}{l}\text { All machine equipment should use electric } \\
\text { energy for process monitoring, where working } \\
\text { voltage is increased in order to reduce power } \\
\text { consumption, thus, shock hazard is increased. }\end{array}$ & $\begin{array}{l}\text { How to reduce the energy consumption of } \\
\text { process is considered from the source of } \\
\text { the process; when the expected process } \\
\text { goal can be attained, shock prevention } \\
\text { design shall be implemented. }\end{array}$ \\
\hline sions & $\begin{array}{l}\text { As highly flammable explosives, silicomethane } \\
\text { and boroethane, are used in high-tech } \\
\text { processes, any accidental leakage will cause } \\
\text { fires and explosions. }\end{array}$ & $\begin{array}{l}\text { The process design shall be reviewed from } \\
\text { the inherently safer design strategies of } \\
\text { intensification, substitution, and } \\
\text { attenuation, thus, hazards are unlikely to } \\
\text { occur, or will be less serious when they do } \\
\text { occur. }\end{array}$ \\
\hline Poisc & $\begin{array}{l}\text { As high-tech processes use toxic gases, such as } \\
\text { silicomethane, boroethane, phosphine, and } \\
\text { arsine, and hazardous liquid, such as organic } \\
\text { solvents and hydrofluoric acid, any accidental } \\
\text { leakage will cause inhalation or contact } \\
\text { poisoning. }\end{array}$ & $\begin{array}{l}\text { The process design can be reviewed by } \\
\text { using less toxic reacting substances or } \\
\text { lower process reaction temperature, thus, } \\
\text { reducing the likelihood of poisoning. }\end{array}$ \\
\hline Corrosion & $\begin{array}{l}\text { When strong acid materials, such as sulfuric } \\
\text { acid and hydrofluoric acid, are used in a } \\
\text { process, the direct contact or vapor resulted } \\
\text { from a leak may cause contact corrosion injury. }\end{array}$ & $\begin{array}{l}\text { The size of a process reactor can be } \\
\text { reviewed, and the inherently safer design } \\
\text { strategy of intensification is fully used to } \\
\text { reduce hazards. }\end{array}$ \\
\hline Radiation & $\begin{array}{l}\text { The high-tech ion implantation process and } \\
\text { some detection instruments have potential }\end{array}$ & $\begin{array}{l}\text { The inherently safer design strategy of } \\
\text { attenuation shall be reviewed, or }\end{array}$ \\
\hline
\end{tabular}




\begin{tabular}{|l|l|l|}
\hline & $\begin{array}{l}\text { radiant energy, and an accidental leak will } \\
\text { directly affect operating personnel. }\end{array}$ & $\begin{array}{l}\text { limitation of effects is adopted for } \\
\text { shielding, in order to eliminate potential } \\
\text { hazards. }\end{array}$ \\
\hline Burn and scald & $\begin{array}{l}\text { The high-tech plant has partial facility systems } \\
\text { (e.g. zeolite concentration rotor) with a } \\
\text { combustion chamber, and if it is opened during } \\
\text { operation, there may be burn or scald. }\end{array}$ & $\begin{array}{l}\text { Can occur at the facility end, and } \\
\text { combustion technology can be replaced by } \\
\text { recovery techniques, thus, the substitution } \\
\text { strategy of inherently safer design } \\
\text { strategies is a feasible program. }\end{array}$ \\
\hline
\end{tabular}

Table 6 Discussion regarding the NAND Flash process design of ISD strategies

\begin{tabular}{|c|c|c|}
\hline Structure & Material & Key points in process design and safety review \\
\hline $\begin{array}{l}\text { Silicon } \\
\text { substrate }\end{array}$ & $\begin{array}{l}\text { Semiconductor } \\
\text { silicon }\end{array}$ & $\begin{array}{l}\text { 1. The crystalline silicon rod for cutting wafers is implemented in the raw } \\
\text { material plant at present. } \\
\text { 2. The process design only places emphasis on cleaning before the process, } \\
\text { and the main potential hazards are fires, explosions, poisoning, and } \\
\text { corrosion. }\end{array}$ \\
\hline $\begin{array}{l}\text { Hard mask } \\
\text { layer }\end{array}$ & $\mathrm{SiH} 2 \mathrm{Cl} 2, \mathrm{NH} 3$ & $\begin{array}{l}\text { 1. The CVD process is used, thus, temperature, mole fraction (mf), flow rate } \\
(\mathrm{F}) \text {, and pressure }(\mathrm{P}) \text { parameters are important design points of this process. } \\
\text { 2. The potential hazards of temperature effect, high temperature contact, } \\
\text { mole fraction, flow rate, and pressure can influence the potential hazards of } \\
\text { fire, explosion, poisoning, and corrosion. }\end{array}$ \\
\hline $\begin{array}{l}\text { Well } \\
\text { doping }\end{array}$ & $\begin{array}{l}\text { PH3, BF3, } \\
\text { AsH3, BCl3 }\end{array}$ & $\begin{array}{l}\text { 1. Furnace high temperature diffusion process was adopted in the past. } \\
\text { 2. The advanced methods use the ion implantation method, the full wafer } \\
\text { implantation process is directly implemented, and the process is controlled } \\
\text { by time and energy. } \\
\text { 3. There are potential hazards of fire, explosion, poisoning, and corrosion in } \\
\text { this process. }\end{array}$ \\
\hline $\begin{array}{l}\text { Source and } \\
\text { drain } \\
\text { regions }\end{array}$ & $\begin{array}{l}\mathrm{PH} 3, \quad \mathrm{BF} 3, \\
\mathrm{AsH} 3, \mathrm{BCl} 3\end{array}$ & $\begin{array}{l}\text { 1. Two-stage process. } \\
\text { 2. First, low concentration doping is implemented by ion implantation, then } \\
\text { high concentration doping is implemented using ion implantation, and the } \\
\text { machine uses extensive magnetic fields and radioactive sources to screen the }\end{array}$ \\
\hline
\end{tabular}




\begin{tabular}{|c|c|c|}
\hline & & $\begin{array}{l}\text { mass of ion. } \\
\text { 3. The process design shall place emphasis on highly hazardous reacting } \\
\text { substances and energy, and there are potential hazards of high temperature, } \\
\text { fire, explosion, poisoning, radiation, and corrosion in the process. }\end{array}$ \\
\hline $\begin{array}{l}\mathrm{SiO} 2 \\
\text { isolation } \\
\text { dielectric } \\
\text { layer }\end{array}$ & $\mathrm{SiH} 4, \mathrm{TEOS}$ & $\begin{array}{l}\text { 1. Batch furnace or monolithic thin film machine can be used for CVD. } \\
\text { 2. The temperature, mole fraction (mf), flow rate (F), and pressure (P) } \\
\text { parameters are important design points of this process. } \\
\text { 3. The potential hazards of temperature effect, high temperature contact, } \\
\text { mole fraction, flow rate, and pressure can influence the potential hazards of } \\
\text { fire, explosion, poisoning, and corrosion. }\end{array}$ \\
\hline $\begin{array}{l}\text { Storage } \\
\text { area and } \\
\text { control gate } \\
\text { poly }\end{array}$ & $\mathrm{SiH} 4$ & $\begin{array}{l}\text { 1. LPCVD process is mostly used for deposition. } \\
\text { 2. The temperature, mole fraction (mf), flow rate }(\mathrm{F}) \text {, and pressure }(\mathrm{P}) \\
\text { parameters are important design points of this process. } \\
\text { 3. There are potential hazards of high temperature, fire, explosion, and } \\
\text { poisoning in this process. }\end{array}$ \\
\hline $\begin{array}{l}\text { Contact } \\
\text { window and } \\
\text { metal } \\
\text { online }\end{array}$ & $\begin{array}{lr}\mathrm{Al}, & \text { tungsten, } \\
\mathrm{TiCl} 4, & \text { WF6, } \\
\mathrm{NH} 3 & \end{array}$ & $\begin{array}{l}\text { 1. The sputtering of PVD is used for wire thickness greater than } 90 \mathrm{~nm} \text {, where } \\
\text { the plasma impinges the target material to make the material fall on the wafer } \\
\text { surface. } \\
\text { 2. The CVD process is used for wire thickness smaller than } 90 \mathrm{~nm} \text {, and the } \\
\text { Damascene approach of CMP is used, the CVD process still places emphasis } \\
\text { on the design of temperature, mole fraction (mf), flow rate (F), and pressure } \\
\text { (P) parameters. } \\
\text { 3. There are potential hazards of fire, explosion, poisoning, and corrosion in } \\
\text { this process. }\end{array}$ \\
\hline $\begin{array}{l}\text { Metal } \\
\text { online } \\
\text { dielectric } \\
\text { layer }\end{array}$ & $\mathrm{SiH} 4, \mathrm{TEOS}$ & $\begin{array}{l}\text { 1. The CVD process is used, thus, the temperature, mole fraction (mf), flow } \\
\text { rate }(\mathrm{F}) \text {, and pressure }(\mathrm{P}) \text { parameters are important design points of this } \\
\text { process. } \\
\text { 2. The potential hazards of temperature effect, high temperature contact, } \\
\text { mole fraction, flow rate, and pressure influence the potential hazards of fire, } \\
\text { explosion, poisoning, and corrosion. }\end{array}$ \\
\hline $\begin{array}{l}\text { Lithography } \\
\text { operation of }\end{array}$ & $\begin{array}{l}\text { AZP4620 } \\
\text { photoresist, }\end{array}$ & 1. Advanced processes mostly use integrated machines for complete \\
\hline
\end{tabular}




\begin{tabular}{|c|c|c|}
\hline $\begin{array}{l}\text { various } \\
\text { structures }\end{array}$ & $\begin{array}{l}\mathrm{S} 1813 \\
\text { photoresist, } \\
\mathrm{HMDS} \text { (bottom } \\
\text { sizing), n-butyl } \\
\text { acetate } \\
\text { (development), } \\
\mathrm{NaOH} \\
\text { (development), } \\
\text { acetone } \\
\text { (photoresist } \\
\text { removal), } \\
\mathrm{H} 2 \mathrm{SO} 4, \mathrm{H} 2 \mathrm{O} 2\end{array}$ & $\begin{array}{l}\text { lithography operation. } \\
\text { 2. The process sequence is cleaning, photoresist spincoating, soft bake, } \\
\text { exposure, hard bake, and finally, the etching process. } \\
\text { 3. The photolithography process mostly considers monolithic operation, } \\
\text { temperature, reactant addition, and operating time as the key points of } \\
\text { design. } \\
\text { 4. There are potential hazards of fire, explosion, poisoning, and corrosion in } \\
\text { this process. }\end{array}$ \\
\hline $\begin{array}{l}\text { Etching } \\
\text { operation of } \\
\text { various } \\
\text { structures }\end{array}$ & $\begin{array}{l}\text { CF4, CHF3, O2, } \\
\text { SF6 (SiO2, Poly, } \\
\text { TiN, } \\
\text { H2SO4, H3PO4, } \\
\text { HCl, }\end{array}$ & $\begin{array}{l}\text { 1. Wet etching has high particulate contamination; however, it is the first } \\
\text { choice for increasing productive capacity, due to its batch process } \\
\text { characteristics and rapid reaction. However, the consumption of chemicals is } \\
\text { high due to batch reaction, and as the machine is combined with ultrasonic } \\
\text { vibration technology and heating, the process is likely to generate a lot of } \\
\text { harmful vapor, thus, there are potential hazards of fire, explosion, poisoning, } \\
\text { and corrosion in this process. } \\
\text { 2. Dry etching uses plasma and heating to accelerate reaction, the etching } \\
\text { quality is likely to be mastered, and there are potential hazards of fire, } \\
\text { explosion, poisoning, and corrosion in this process. }\end{array}$ \\
\hline $\begin{array}{l}\text { CMP } \\
\text { operation } \\
\text { for structure } \\
\text { flattening }\end{array}$ & $\begin{array}{l}\mathrm{KOH}, \quad \mathrm{H} 2 \mathrm{O} 2, \\
\mathrm{NH} 4 \mathrm{OH}, \\
\text { trichloroethylene, } \\
\mathrm{HF}, \quad \text { acetone, } \\
\mathrm{H} 2 \mathrm{SO} 4\end{array}$ & $\begin{array}{l}\text { 1. The chemicals for polishing, polishing rate, and polishing time are the key } \\
\text { points in the CMP process design. } \\
\text { 2. There are potential hazards of poisoning and corrosion in this process. }\end{array}$ \\
\hline
\end{tabular}

Table 7 Integration of 22nmNAND Flash design specifications after applied ISD strategies

\begin{tabular}{|l|l|l|}
\hline Structure & Width $\mathrm{nm}$ & Space $\mathrm{nm}$ \\
\hline Well & 106 & 172 \\
\hline OD (Transistor) & 28 & 36 \\
\hline OD (Interconnection) & 28 & 36 \\
\hline Poly 1(on STI) & 22 & 31 \\
\hline
\end{tabular}




\begin{tabular}{|l|l|l|}
\hline Poly 1(on OD) & 22 & 31 \\
\hline Contact & 28 & 31 \\
\hline Metal-1 & 29 & 29 \\
\hline Metal layer contact window Via-1/2/3/4 & 32 & 32 \\
\hline Metal-2/3/4/5 & 36 & 36 \\
\hline Metal layer contact window Via-5/6/7/8 & 44 & 43 \\
\hline Metal-6/7/8 & 48 & 50 \\
\hline Metal-9(Thin, $0.5 \mu \mathrm{m}$ top metal) & 480 & 288 \\
\hline
\end{tabular}

Table 8 Process design and adjustment proposal after applied ISD strategies

\begin{tabular}{|c|c|c|}
\hline $\begin{array}{c}\text { Subject of } \\
\text { Process design }\end{array}$ & $\begin{array}{c}\text { Ideas of inherently } \\
\text { safer design strategies }\end{array}$ & Expected results \\
\hline $\begin{array}{l}\text { Reduction of } \\
\text { existing } \\
\text { process } \\
\text { materials }\end{array}$ & $\begin{array}{l}\text { Intensification: the } \\
\text { necessary minimum } \\
\text { consumption for the } \\
\text { process is adopted, as } \\
\text { possible. Therefore, the } \\
\text { materials for various } \\
\text { processes shall be } \\
\text { evaluated, the } \\
\text { specifications and } \\
\text { addition of each batch } \\
\text { of chemicals are listed, } \\
\text { and then the reduction } \\
\text { proposal is considered. }\end{array}$ & $\begin{array}{l}\text { When the process material consumption } \\
\text { is reduced, the reacting gas and chemicals } \\
\text { will be reduced. The process materials } \\
\text { can be reduced by appropriately adjusting } \\
\text { the reaction time and temperature, } \\
\text { provided production capacity is not } \\
\text { influenced, or process tools with small } \\
\text { reactors are selected. }\end{array}$ \\
\hline $\begin{array}{l}\text { Change } \\
\text { existing } \\
\text { process } \\
\text { materials }\end{array}$ & $\begin{array}{l}\text { Substitution: } \\
\text { hazardous materials } \\
\text { are substituted by safe } \\
\text { chemical substances, } \\
\text { as possible. Therefore, } \\
\text { the present materials } \\
\text { with potential hazards } \\
\text { can be substituted by } \\
\text { safe materials. }\end{array}$ & $\begin{array}{l}\text { Strong acid is substituted by weak acid, } \\
\text { inflammable material is substituted by } \\
\text { noncombustible material, and highly toxic } \\
\text { material is substituted by innoxious } \\
\text { substance, thus, even if there is a leak, } \\
\text { contact will not cause severe hazards. }\end{array}$ \\
\hline $\begin{array}{l}\text { Adjustment of } \\
\text { process }\end{array}$ & $\begin{array}{l}\text { Attenuation: hazardous } \\
\text { materials should be }\end{array}$ & $\begin{array}{l}\text { The reaction parameters can be low } \\
\text { temperature, low pressure, low power }\end{array}$ \\
\hline
\end{tabular}




\begin{tabular}{|l|l|l|}
\hline parameters & $\begin{array}{l}\text { used under minimum } \\
\text { hazardous conditions. }\end{array}$ & $\begin{array}{l}\text { consumption, and low mechanical power, } \\
\text { thus, the possibility of hazard is lower. }\end{array}$ \\
\hline
\end{tabular}

Table 9 Furnace process setting conditions after applied ISD strategies

\begin{tabular}{|c|c|c|c|c|}
\hline Factor & Units & Level(-) & Level(0) & Level(+) \\
\hline Temperature & ${ }^{\circ} C$ & 600 & 615 & 630 \\
\hline Silane \& TEOS m.f. & - & 0.2 & 0.6 & 1.0 \\
\hline Flow rate & sccm & 130 & 230 & 330 \\
\hline Pressure & mTorr & 150 & 325 & 500 \\
\hline
\end{tabular}

Table 10 Test results of product yield, DC property improvement, frequency response improvement, and peeling ability improvement after applied ISD strategies

\begin{tabular}{|c|c|c|c|c|c|}
\hline \multirow{4}{*}{$\begin{array}{c}\text { Item of } \\
\text { experiment }\end{array}$} & Lot Number| & $\begin{array}{c}\text { Product yield } \\
(\%)\end{array}$ & $\begin{array}{c}\text { Improvement of } \\
\text { electrical } \\
\text { characteristics } \\
\text { DC }(\%)\end{array}$ & $\begin{array}{c}\text { Improvement of } \\
\text { Frequency response } \\
(\%)\end{array}$ & $\begin{array}{c}\text { Improvement of } \\
\text { stripping ability } \\
(\%)\end{array}$ \\
\hline \multirow{4}{*}{ Silane } & Lot 1 & 85.32 & 5.56 & 4.58 & 4.46 \\
\cline { 2 - 6 } & Lot 2 & 83.13 & 5.72 & 3.52 & 4.11 \\
\cline { 2 - 6 } & Lot 3 & 84.22 & 6.21 & 3.84 & 3.89 \\
\cline { 2 - 6 } & Lot 4 & 81.28 & 6.66 & 5.37 & 5.17 \\
\cline { 2 - 6 } & Lot 5 & 82.83 & 7.35 & 5.69 & 3.28 \\
\cline { 2 - 6 } & Lot 6 & 83.57 & 6.20 & 5.26 & 4.26 \\
\cline { 2 - 6 } & Lot 7 & 85.76 & 6.03 & 5.91 & 4.22 \\
\cline { 2 - 6 } & Lot 8 & 84.89 & 5.58 & 5.60 & 4.78 \\
\hline \multicolumn{2}{|c|}{ Average of Silane } & $\mathbf{8 3 . 8 8}$ & $\mathbf{6 . 1 6}$ & $\mathbf{4 . 9 7}$ & $\mathbf{4 . 2 7}$ \\
\hline
\end{tabular}




\begin{tabular}{|c|c|c|c|c|c|}
\multirow{4}{*}{} & Lot 9 & 85.51 & 5.99 & 4.81 & 4.36 \\
\cline { 2 - 6 } & Lot 10 & 83.35 & 5.59 & 3.98 & 3.98 \\
\cline { 2 - 6 } TEOS & Lot 11 & 82.16 & 6.82 & 4.59 & 5.69 \\
\cline { 2 - 6 } & Lot 12 & 82.48 & 7.39 & 6.49 & 3.54 \\
\cline { 2 - 6 } & Lot 13 & 86.56 & 6.83 & 4.67 & 4.90 \\
\cline { 2 - 6 } & Lot 14 & 82.18 & 7.74 & 6.24 & 3.81 \\
\cline { 2 - 6 } & Lot 15 & 85.31 & 6.86 & 4.69 & 4.72 \\
\cline { 2 - 6 } & Lot 16 & 86.46 & 6.85 & 5.80 & 3.93 \\
\hline \multicolumn{2}{|c|}{ Average of TEOS } & $\mathbf{8 4 . 2 5}$ & $\mathbf{6 . 7 6}$ & $\mathbf{5 . 1 6}$ & $\mathbf{4 . 3 6}$ \\
\hline
\end{tabular}

Table 11 Integration of SEMI-S2 semiconductor process equipment safety standards

Basic specifications of equipment

\begin{tabular}{|c|c|}
\hline $\begin{array}{l}\text { Safety-related } \\
\text { interlock }\end{array}$ & $\begin{array}{l}\text { 1. The critical safety interlock is defined as critical, high, and medium risk safety interlock } \\
\text { preventers, as identified by risk assessment. } \\
\text { 2. The critical safety interlock shall be composed of a Hardware-based device, such as a } \\
\text { relay, rather than a Firmware-based device, such as ROM, IC, or a Software-based } \\
\text { device, such as PLC or PC. }\end{array}$ \\
\hline Chemicals & $\begin{array}{l}\text { 1. The equipments with hazardous gases must be equipped with a gas detector, and the } \\
\text { sampling location shall be indicated. } \\
\text { 2. Protection for maintenance of equipment includes engineering control (e.g. gas hood, } \\
\text { coffer wall), operating procedures, and personal protection. } \\
\text { 3. If the equipment has chemicals or cooling water, there must be a leak detector, and there } \\
\text { shall be a coffer wall under the equipment to avoid leaking. }\end{array}$ \\
\hline
\end{tabular}




\begin{tabular}{|c|c|}
\hline Ionizing radiation & $\begin{array}{l}\text { 1. Ionizing radiation must be limited at the minimum. } \\
\text { 2. The protective shelter for all hazard points shall be equipped with a safety interlock, } \\
\text { which cannot be dismounted at will, and this interlock shall never fail. }\end{array}$ \\
\hline $\begin{array}{l}\text { Nonionizing } \\
\text { radiation }\end{array}$ & $\begin{array}{l}\text { 1. Ionizing radiation must be limited at the minimum. } \\
\text { 2. There shall be the following protection items for laser equipment according to grade: } \\
\text { - Protective casing. } \\
\text { - Casing safety-related interlock. } \\
\text { - Door leaf safety interlock. } \\
\text { - Separate control panel. } \\
\text { - Power supply control lock. } \\
\text { - Transmitting warning indication. } \\
\text { - Beam attenuator or stop plate. } \\
\text { - To establish a control area. } \\
\text { - Hazard rating label. } \\
\text { - Shutter label. } \\
\text { - Instruction manual. } \\
\text { - Mutual wood equipment. } \\
\text { - Protective clothing. } \\
\text { - Warning label. } \\
\text { - Operational training guidance. }\end{array}$ \\
\hline Audio noise & Noise shall not exceed $80 \mathrm{~dB}$. \\
\hline $\begin{array}{l}\text { Ventilation and } \\
\text { exhaust }\end{array}$ & $\begin{array}{l}\text { 1. There must be an exhaust air flow interlock (generally a pressure difference detector), } \\
\text { which raises a visible and audible alarm, and the lower bound set point of the alarm is } \\
\text { recommended as } 1 / 2 \text { or } 1 / 3 \text { of the normal operational value. } \\
\text { 2. The gas exhaust piping shall be made of stainless steel (partially nonmetal material for } \\
\text { preventing electric conduction), and if there may be corrosive gases, the inside of the } \\
\text { pipeline shall be treated for corrosion prevention. }\end{array}$ \\
\hline
\end{tabular}


1. There shall be nonconducting or grounded protective solid barriers in the following conditions:

- Somewhere near the hazard.

- Short circuit or electric arc caused by falling object.

- Liquid inside equipment flows into electrical components as equipment fails.

- Above the main circuit breaker wire side.

- Maintenance or service during contact with probably uninsulated parts (latent power greater than $30 \mathrm{~V}$ RMS value, $42.2 \mathrm{~V}$ peak, $60 \mathrm{~V} \mathrm{DC}$, or $240 \mathrm{VA}$ ).

Electrical

2. Important components, such as UPS, pump, chiller, heat exchanger, RF generator, and heat controller, must be authenticated by NRTL.

3. Wire shall be color coded, or there shall be recognizable labels on both ends of wires.

4. There shall be an overcurrent protection component and main shutoff device for at least $10,000 \mathrm{rms}$ AIC.

5. Main circuit breaker shall be designed with an energy blockout (e.g. lockout).

6. Leak current $\leqq 3.5 \mathrm{~mA}$.

7. Resistance of ground circuit $\leqq 0.1 \Omega$

8. If there is a space with inflammable gas or inflammable vapor in the equipment, the electrical components shall be explosion proof.

1. Hazardous voltage and power greater than $240 \mathrm{~V}-\mathrm{A}$ in the equipment shall be deenergized when EMO is started.

- Exception 1: non-hazardous voltage (basically $24 \mathrm{~V}$ ) maintains power.

- Exception 2: safety-related components (e.g. smoke detector, gas/water leak detector, pressure gauging component), which are powered by non-hazardous power supply, can still be powered on.

- Exception 3: if all electric energy breakers, sockets, and electricity supply conductor terminals have apparent marks, the computer system can be powered continuously. The hazardous energy supplied with power after the EMO is started

Emergency

shutdown shall be isolated or contained in order to avoid casual contact with maintenance personnel.

2. The circuit must be a hardware-based device.

3. Manual reset is required.

4. Red straw mushroom shape is required, with yellow background.

5. There must be explicit Chinese and English marks.

6. It must be easy to touch, its size shall be suitable for the base of palm to start.

7. The periphery of the button can be appropriately enclosed to avoid misoperation.

8. There must be an EMO button within $3 \mathrm{~m}$ to any personnel. 


\begin{tabular}{|c|c|}
\hline $\begin{array}{l}\text { Robotics and } \\
\text { automation }\end{array}$ & $\begin{array}{l}\text { 1. The cassette access door must be provided with protection to avoid injuring hands. } \\
\text { 2. Robot must be protected, the robot must be stopped when the door is opened. }\end{array}$ \\
\hline Hazard warning & $\begin{array}{l}\text { 1. The inside and outside of the machine must have Chinese and English hazard warning } \\
\text { labels. } \\
\text { 2. Labels shall conform to the SEMI S1 standard. }\end{array}$ \\
\hline $\begin{array}{l}\text { Earthquake } \\
\text { protection }\end{array}$ & $\begin{array}{l}\text { 1. Equipment with hazardous materials must be able to bear a horizontal load, which is } \\
94 \% \text { of the installation weight on the equipment mass center; equipment without } \\
\text { hazardous materials must be able to bear a horizontal load, which is } 63 \% \text { of installation } \\
\text { weight on the equipment mass center. } \\
\text { 2. The machine body and auxiliary equipments shall be able to bear } 0.35 \mathrm{~g} \text { earthquake } \\
\text { without tilting or displacement. } \\
\text { 3. Pipeline containers with hazardous materials in the machine shall be able to bear } 0.35 \mathrm{~g} \\
\text { without breakup or leak. } \\
\text { 4. If there are tie-ins, attachments, or seismic anchorage points, the positions must be } \\
\text { specifically marked. }\end{array}$ \\
\hline Fire protection & $\begin{array}{l}\text { 1. Combustible matter and potential ignition sources should not be contacted. } \\
\text { 2. Settings of fire detection and fire suppression systems shall be considered. }\end{array}$ \\
\hline
\end{tabular}

